[Chem. Pharm. Bull.

35( 3 )1016-1029(1987)

\title{
Selective Deoxygenation via Regioselective Thioacylation of Non-protected Glycopyranosides by the Dibutyltin Oxide Method ${ }^{11}$
}

\author{
Mohammed Ekramul Haque, ${ }^{a}$ Tohru Kikuchi, ${ }^{*},{ }^{a}$ Kimihiro Kanemitsu, ${ }^{b}$ \\ and YoSHISUKE TSUDA $* . b$ \\ Research Institute for Wakan-Yaku (Oriental Medicines), Toyama Medical and \\ Pharmaceutical University, 2630 Sugitani, Toyama 930-01, Japan and \\ Faculty of Pharmaceutical Sciences, Kanazawa University, ${ }^{b}$ \\ 13-1 Takara-machi, Kanazawa 920, Japan
}

(Received August 25, 1986)

\begin{abstract}
Regioselective thioacylation of some non-protected glycopyranosides (Me $\alpha$-D-Glc, Me $\beta$-DGlc, Me $\alpha$-D-Xyl, Me $\beta$-D-Xyl) was examined by the dibutyltin oxide method, using phenoxythiocarbonyl chloride as the thioacylating agent. This method gave the mono-thionocarbonates regioselectively in high yields. Acetylation of these thionocarbonates followed by deoxygenation with tributyltin hydride smoothly gave the corresponding deoxy derivatives, except for the primary thionocarbonates. Similar treatment of the pyranosides that have a cis-vicinal glycol (Me $\alpha$-D-Gal, Me $\beta$-D-Gal, Me $\beta$-L-Ara, and Ph $\alpha$-L-Ara) led to the formation of cyclic thionocarbonates, which on acetylation followed by olefination with trimethyl phosphite afforded the unsaturated derivatives in satisfactory yields. On deacetylation and subsequent hydrogenation over platinic oxide, they gave the corresponding dideoxy derivatives quantitatively. The compounds thus prepared were identified by analyses of their proton and carbon-13 nuclear magnetic resonance spectra.
\end{abstract}

Keywords_- glycopyranoside; regioselective thioacylation; dibutyltin oxide; deoxygenation; cis-vicinal glycol; thionocarbonate; cyclic thionocarbonate; deoxy, dideoxy sugar; unsaturated sugar; ${ }^{13} \mathrm{C}-\mathrm{NMR}$

\section{Introduction}

Thiocarbonyl esters of the secondary alcohols are reduced by tributyltin hydride to give the deoxygenated derivatives, usually in high yields. ${ }^{2)}$ In the cases of poly-hydroxy compounds (such as carbohydrates), protection of those hydroxyl groups which need not be involved in the reaction is necessary prior to the thioacylation. In our previous paper we reported the regioselective acylation ${ }^{3)}$ and alkylation ${ }^{4)}$ of some non-protected glycopyranosides by using tin compounds. From those results, it is evident that the method using dibutyltin oxide permits regioselective acylation and alkylation of a particular secondary hydroxyl group instead of a primary hydroxyl group, and thus thioacylation is also expected to occur in a similar manner. This reaction, in combination with deoxygenation, should allow the preparation of deoxy sugars regioselectively, providing useful intermediates for the synthesis of natural products from easily available carbohydrates. However, the utility of this approach needs to be established.

In this paper, we describe the selective deoxygenation of some non-protected glycopyranosides via regioselective thioacylation by the dibutyltin oxide method.

\section{Results and Discussion}

\section{Thioacylation}

Among the reagents tested for thioacylation, phenoxythiocarbonyl chloride ${ }^{5)}$ was found 
to be the most suitable for the preparation of monothionocarbonates by the $\mathrm{Bu}_{2} \mathrm{SnO}$ method. Thioacylation with other reagents, such as $p$-methoxythiobenzoyl chloride, requires prolonged reaction time (5-6h) and elevated temperature, even in the presence of catalysts (for example, 4-dimethylaminopyridine). Under such vigorous conditions, the yields of the desired products as well as the selectivity were reduced, and in most cases, migration of the thioacyl group also occurred. Moreover, an appreciable formation of di-p-methoxythionobenzoate was observed.

On the other hand, when phenoxythiocarbonyl chloride was used, the regioselectivity as well as the yields of the monothionocarbonates were excellent and the dithionocarbonates were not formed. For example, the stannylene derivative of methyl $\beta$-D-xylopyranoside (11), when reacted with $1.1 \mathrm{~mol}$ eq of phenoxythiocarbonyl chloride in dioxane at room temperature, gave the 4-thionocarbonate (12a) quantitatively within $1 \mathrm{~h}$, without any catalyst.

Identification of each product and determination of the product composition were done as described in a previous paper ${ }^{3)}$ by analysis of the carbon-13 nuclear magnetic resonance $\left({ }^{13} \mathrm{C}\right.$-NMR) spectra (Table I). In most cases, the monothionocarbonates obtained by the reaction could be completely analyzed by taking account of the thioacylation shifts (estimated from the acylation shift rule) with respect to the non-acylated compounds. Moreover, the proton nuclear magnetic resonance $\left({ }^{1} \mathrm{H}-\mathrm{NMR}\right)$ signals of all methine protons could be completely assigned by successive proton decoupling experiments on the acetylated derivatives (see Experimental).

Stannylation was carried out with $\mathrm{Bu}_{2} \mathrm{SnO}(1.5 \mathrm{~mol}$ eq) in refluxing dry methanol as described in a previous paper. ${ }^{3)}$ In parallel with the result of acylation, methyl $\alpha$-D-

TABLE I. ${ }^{13} \mathrm{C}$-Chemical Shifts of Monothionocarbonates and Cyclic Thionocarbonates of Some Hexoand Pentopyranosides and Their Thioacylation Shift Values (in Parentheses) in Pyridine- $d_{5}$

\begin{tabular}{|c|c|c|c|c|c|c|c|c|}
\hline Thionocarbonate & C-1 & $\mathrm{C}-2$ & $\mathrm{C}-3$ & C-4 & $C-5$ & C-6 & $\mathrm{OMe}$ & $\mathrm{C}=\mathrm{S}$ \\
\hline Me $\alpha$-D-Glc (1) & 101.3 & 73.7 & 75.3 & 72.0 & 74.0 & 62.7 & 55.0 & \\
\hline $\begin{array}{l}\text { 2-Phenyl thionocarbonate } \\
\text { (2a) }\end{array}$ & $\begin{array}{c}96.7 \\
(-4.6)\end{array}$ & $\begin{array}{r}84.3 \\
(+10.6)\end{array}$ & $\begin{array}{c}71.7 \\
(-3.6)\end{array}$ & $\begin{array}{l}72.0 \\
(0)\end{array}$ & $\begin{array}{c}74.1 \\
(+0.1)\end{array}$ & $\begin{array}{c}62.1 \\
(-0.6)\end{array}$ & $\begin{array}{c}54.9 \\
(-0.1)\end{array}$ & 195.8 \\
\hline $\mathrm{Me} \beta$-D-Glc (4) & 105.5 & 74.9 & 78.2 & 71.4 & 78.2 & 62.6 & 56.7 & \\
\hline $\begin{array}{l}\text { 6-Phenyl thionocarbonate } \\
\text { (5) }\end{array}$ & $\begin{array}{c}105.7 \\
(+0.2)\end{array}$ & $\begin{array}{l}74.9 \\
(0)\end{array}$ & $\begin{array}{l}78.2 \\
(0)\end{array}$ & $\begin{array}{c}71.2 \\
(-0.2)\end{array}$ & $\begin{array}{c}74.7 \\
(-3.5)\end{array}$ & $\begin{array}{r}74.7 \\
(+12.1)\end{array}$ & $\begin{array}{c}56.8 \\
(+0.1)\end{array}$ & 195.6 \\
\hline $\operatorname{Me} \alpha-D-X y l(6)$ & 101.5 & 73.7 & 75.5 & 71.4 & 63.1 & & 55.1 & \\
\hline $\begin{array}{l}\text { 2-Phenyl thionocarbonate } \\
\text { (7a) }\end{array}$ & $\begin{array}{c}97.1 \\
(-4.4)\end{array}$ & $\begin{array}{r}84.4 \\
(+10.7)\end{array}$ & $\begin{array}{c}72.3 \\
(-3.2)\end{array}$ & $\begin{array}{l}71.4 \\
(0)\end{array}$ & $\begin{array}{c}62.9 \\
(-0.2)\end{array}$ & & $\begin{array}{l}55.1 \\
(0)\end{array}$ & 195.9 \\
\hline $\begin{array}{l}\text { 4-Phenyl thionocarbonate } \\
\text { (8a) }\end{array}$ & $\begin{array}{c}101.4 \\
(-0.1)\end{array}$ & $\begin{array}{c}73.6 \\
(-0.1)\end{array}$ & $\begin{array}{c}71.6 \\
(-3.9)\end{array}$ & $\begin{array}{r}83.0 \\
(+11.6)\end{array}$ & $\begin{array}{c}57.9 \\
(-5.2)\end{array}$ & & $\begin{array}{c}55.4 \\
(+0.3)\end{array}$ & 195.7 \\
\hline $\mathrm{Me} \beta$-D-Xyl (11) & 106.0 & 74.6 & 78.1 & 70.9 & 67.0 & & 56.6 & \\
\hline $\begin{array}{l}\text { 4-Phenyl thionocarbonate } \\
\text { (12a) }\end{array}$ & $\begin{array}{c}106.0 \\
(0)\end{array}$ & $\begin{array}{c}74.8 \\
(+0.2)\end{array}$ & $\begin{array}{c}74.3 \\
(-3.8)\end{array}$ & $\begin{array}{r}82.9 \\
(+12.0)\end{array}$ & $\begin{array}{c}62.0 \\
(-5.0)\end{array}$ & & $\begin{array}{c}56.8 \\
(+0.2)\end{array}$ & 195.6 \\
\hline Me $\alpha$-D-Gal (15) & 101.5 & 70.3 & 71.5 & 70.8 & 72.4 & 62.5 & 55.0 & \\
\hline $\begin{array}{l}\text { 3,4-Thionocarbonate } \\
\text { (16a) }\end{array}$ & $\begin{array}{c}99.8 \\
(-1.7)\end{array}$ & $\begin{array}{c}67.9 \\
(-2.4)\end{array}$ & $\begin{array}{r}83.4 \\
(+11.9)\end{array}$ & $\begin{array}{r}81.2 \\
(+10.4)\end{array}$ & $\begin{array}{c}68.6 \\
(-3.8)\end{array}$ & $\begin{array}{c}60.8 \\
(-1.7)\end{array}$ & $\begin{array}{c}55.6 \\
(+0.6)\end{array}$ & 192.6 \\
\hline Me $\beta$-D-Gal (13) & 106.1 & 72.3 & 75.1 & 70.1 & 76.8 & 62.2 & 56.6 & \\
\hline $\begin{array}{l}\text { 3,4-Thionocarbonate } \\
\text { (14a) }\end{array}$ & $\begin{array}{l}103.6 \\
(-2.5)\end{array}$ & $\begin{array}{c}71.4 \\
(-0.9)\end{array}$ & $\begin{array}{c}84.8 \\
(+9.7)\end{array}$ & $\begin{array}{r}80.8 \\
(+10.7)\end{array}$ & $\begin{array}{r}72.9 \\
(-3.9)\end{array}$ & $\begin{array}{c}61.0 \\
(-1.2)\end{array}$ & $\begin{array}{l}56.6 \\
(0)\end{array}$ & 192.6 \\
\hline Me $\beta$-L-Ara $(20)$ & 102.0 & 70.4 & 70.8 & 70.0 & 63.8 & & 55.3 & \\
\hline $\begin{array}{l}\text { 3,4-Thionocarbonate } \\
\text { (21a) }\end{array}$ & $\begin{array}{c}99.7 \\
(-2.3)\end{array}$ & $\begin{array}{c}68.6 \\
(-1.8)\end{array}$ & $\begin{array}{c}82.9 \\
(+12.1)\end{array}$ & $\begin{array}{r}80.9 \\
(+10.9)\end{array}$ & $\begin{array}{c}57.6 \\
(-6.2)\end{array}$ & & $\begin{array}{c}55.8 \\
(+0.5)\end{array}$ & 192.5 \\
\hline $\mathrm{Ph} \alpha$-L-Ara $(\mathbf{1 8})$ & 102.7 & 72.0 & 74.4 & 69.3 & 67.2 & & & \\
\hline $\begin{array}{l}\text { 3,4-Thionocarbonate } \\
\text { (19a) }\end{array}$ & $\begin{array}{c}99.2 \\
(-2.5)\end{array}$ & $\begin{array}{c}70.2 \\
(-1.8)\end{array}$ & $\begin{array}{c}83.7 \\
(+9.3)\end{array}$ & $\begin{array}{r}79.6 \\
(+10.3)\end{array}$ & $\begin{array}{c}61.6 \\
(-5.6)\end{array}$ & & & 192.4 \\
\hline
\end{tabular}



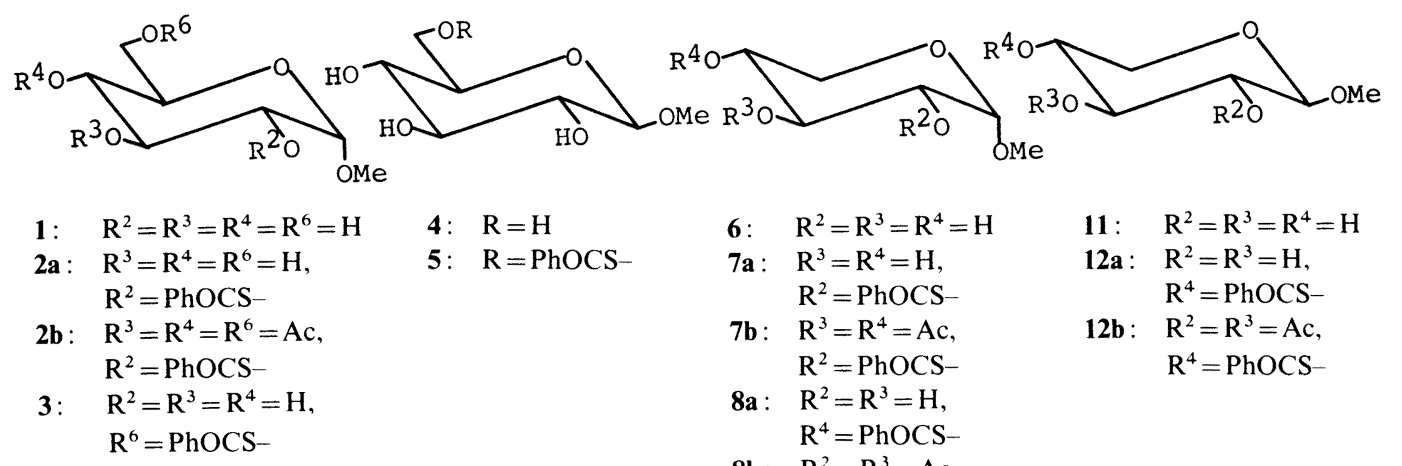

$$
\begin{array}{ll}
\text { 6: } & \mathrm{R}^{2}=\mathrm{R}^{3}=\mathrm{R}^{4}=\mathrm{H} \\
\text { 7a: } & \mathrm{R}^{3}=\mathrm{R}^{4}=\mathrm{H} \\
& \mathrm{R}^{2}=\mathrm{PhOCS}- \\
\text { 7b: } & \mathrm{R}^{3}=\mathrm{R}^{4}=\mathrm{Ac} \\
& \mathrm{R}^{2}=\text { PhOCS- } \\
\mathbf{8 a}: & \mathrm{R}^{2}=\mathrm{R}^{3}=\mathrm{H} \\
& \mathrm{R}^{4}=\text { PhOCS-} \\
\text { 8b: } & \mathrm{R}^{2}=\mathrm{R}^{3}=\mathrm{Ac} \\
& \mathrm{R}^{4}=\text { PhOCS- }
\end{array}
$$

Chart 1

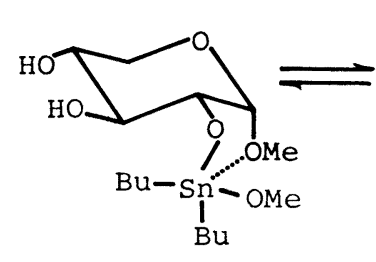

9

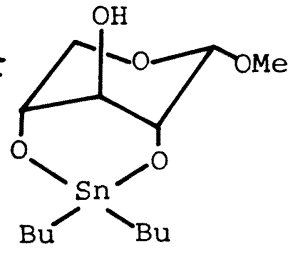

10

Chart 2

glucopyranoside (1) on stannylation followed by thioacylation with phenoxythiocarbonyl chloride at room temperature gave the 2- and 6-thionocarbonates (2a and 3) in $83.0 \%$ yield, the 2-thionocarbonate (2a) was the major product and the 6-thionocarbonate was the minor product (Table II). On similar treatment, methyl $\beta$-D-glucopyranoside (4) gave the 6thionocarbonate (5) as the sole product in $84.8 \%$ yield (Table II).

Reduced regioselectivity in thioacylation was observed for methyl $\alpha$-D-xylopyranoside (6), which yielded the 2- and 4-thionocarbonates (7a and 8a) in the ratio of 54:46 (Table II). This result is parallel with that of acylation ${ }^{3)}$ and could be ascribed to a partial contribution of the cyclic tin intermediate $\mathbf{1 0}$ besides the major contribution of $\mathbf{9}$.

On the other hand, it is interesting that the thioacylation of the pyranosides that have a cis-vicinal glycol produced the cyclic thionocarbonates in high yields. The direct preparation of cyclic thionocarbonates from non-protected sugars by using other reagents, such as thiocarbonyldiimidazole $^{6)}$ or thiophosgene ${ }^{7)}$ gave poor results, so the above method represents a facile procedure to obtain the cyclic thionocarbonates without protecting the other hydroxyl groups. The formation of cyclic thionocarbonates, however, reduces the regioselectivity of deoxygenation, but these products should be useful as intermediates for the synthesis of unsaturated and dideoxy sugars. The mechanism of cyclic thionocarbonate formation is shown in Chart 3.

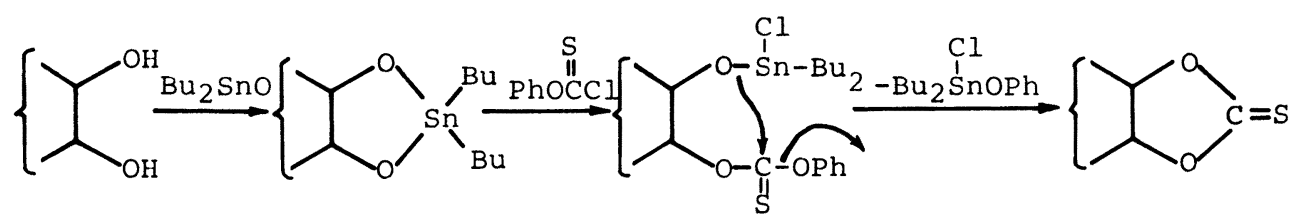


Thus, methyl $\beta$-D-galactopyranoside (13) on stannylation followed by thioacylation gave a cyclic thionocarbonate (14a) as a syrup in $85.3 \%$ yield with a trace of other thionocarbonates. This compound (14a) exhibited no aromatic proton signals in its ${ }^{1} \mathrm{H}-\mathrm{NMR}$ spectrum, but a signal at $\delta 192.6$ due to $\mathrm{C}=\mathrm{S}$ was observed in the ${ }^{13} \mathrm{C}-\mathrm{NMR}$ spectrum. On acetylation it gave the 2,6-diacetate (14b) quantitatively as colorless needles, $\mathrm{mp} 94-96^{\circ} \mathrm{C}$. This compound showed two acetyl signals in its ${ }^{1} \mathrm{H}-\mathrm{NMR}$ spectrum and the $\mathrm{H}-2$ and $\mathrm{H}_{2}-6$ signals appeared at low field compared with those of the parent compound (14a). On similar treatment, methyl $\alpha$ D-galactopyranoside (15) produced the 3,4-cyclic thionocarbonate (16a) and 6-thionocarbonate (17) in the ratio of $71: 29$ with a combined yield of $71.5 \%$. On acetylation, 16a gave the 2,6-diacetate $(\mathbf{1 6 b})$ quantitatively as colorless needles, $\mathrm{mp} 131-132{ }^{\circ} \mathrm{C}$. The identity of this compound was confirmed by detailed examination of its ${ }^{1} \mathrm{H}-\mathrm{NMR}$ spectrum.

Pentopyranosides, such as phenyl $\alpha$-L-arabinopyranoside (18) and methyl $\beta$-Larabinopyranoside (20) also undergo thioacylation as described above to produce the corresponding 3,4-cyclic thionocarbonates 19a (colorless needles, mp 202-203 ${ }^{\circ} \mathrm{C}$ ) and $\mathbf{2 1 a}$ (syrup) in $94.9 \%$ and $83.2 \%$ yields, respectively (Table III). These products were completely analyzed by successive proton decoupling experiments on their acetylated derivatives $\mathbf{1 9 b}$ and 21b and from the ${ }^{13} \mathrm{C}-\mathrm{NMR}$ spectra.
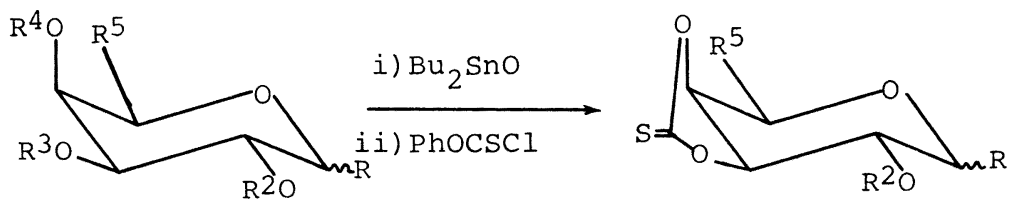

13: $\quad \mathrm{R}^{2}=\mathrm{R}^{3}=\mathrm{R}^{4}=\mathrm{H}, \mathrm{R}^{5}=\mathrm{CH}_{2} \mathrm{OH}, \mathrm{R}=\beta$-OMe

15: $\mathrm{R}^{2}=\mathrm{R}^{3}=\mathrm{R}^{4}=\mathrm{H}, \mathrm{R}^{5}=\mathrm{CH}_{2} \mathrm{OH}, \mathrm{R}=\alpha-\mathrm{OMe}$

17: $\mathrm{R}^{2}=\mathrm{R}^{3}=\mathrm{R}^{4}=\mathrm{H}, \mathrm{R}^{5}=\mathrm{CH}_{2} \mathrm{OCSOPh}, \mathrm{R}=x-\mathrm{OMe}$

14a: $\quad \mathrm{R}^{2}=\mathrm{H}, \mathrm{R}^{5}=\mathrm{CH}_{2} \mathrm{OH}, \mathrm{R}=\beta$-OMe

18: $\mathrm{R}^{2}=\mathrm{R}^{3}=\mathrm{R}^{4}=\mathrm{R}^{5}=\mathrm{H}, \mathrm{R}=\alpha-\mathrm{OPh}$

20: $\quad \mathrm{R}^{2}=\mathrm{R}^{3}=\mathrm{R}^{4}=\mathrm{R}^{5}=\mathrm{H}, \mathrm{R}=\beta$-OMe

14b: $\mathrm{R}^{2}=\mathrm{Ac}, \mathrm{R}^{5}=\mathrm{CH}_{2} \mathrm{OAc}, \mathrm{R}=\beta-\mathrm{OMe}$

16a: $\mathrm{R}^{2}=\mathrm{H}, \mathrm{R}^{5}=\mathrm{CH}_{2} \mathrm{OH}, \mathrm{R}=\alpha$-OMe

16b: $\mathrm{R}^{2}=\mathrm{Ac}, \mathrm{R}^{5}=\mathrm{CH}_{2} \mathrm{OAc}, \mathrm{R}=x-\mathrm{OMe}$

19a: $\mathrm{R}^{2}=\mathrm{R}^{5}=\mathrm{H}, \mathrm{R}=\alpha-\mathrm{OPh}$

19b: $\quad \mathrm{R}^{2}=\mathrm{Ac}, \mathrm{R}^{5}=\mathrm{H}, \mathrm{R}=\alpha-\mathrm{OPh}$

21a: $\quad \mathrm{R}^{2}=\mathrm{R}^{5}=\mathrm{H}, \quad \mathrm{R}=\beta-\mathrm{OMe}$

21b: $\quad \mathrm{R}^{2}=\mathrm{Ac}, \mathrm{R}^{5}=\mathrm{H}, \mathrm{R}=\beta$-OMe

Chart 4

\section{Deoxygenation}

The acetates of the above thionocarbonates undergo smooth deoxygenation when heated at $75-100{ }^{\circ} \mathrm{C}$ with $1-1.5 \mathrm{~mol}$ eq of $\mathrm{Bu}_{3} \mathrm{SnH}$ in toluene with the addition of a catalytic amount of 2,2-azobisisobutyronitrile (AIBN). Under these conditions, methyl $\alpha$-Dglucopyranoside 2-thionocarbonate 3,4,6-triacetate (2b) gave the 2-deoxy compound (22b) in $75.6 \%$ yield. This compound exhibited no aromatic proton signals in its ${ }^{1} \mathrm{H}-\mathrm{NMR}$ spectrum, but it showed two up-field proton signals at $\delta 2.28(1 \mathrm{H}, \mathrm{dd}, J=5.5$ and $13.0 \mathrm{~Hz})$ and at $\delta 1.24$ $\left(1 \mathrm{H}\right.$, ddd, $J=3.5,12.0$, and $13.0 \mathrm{~Hz}$ ) due to $\mathrm{H}_{2}-2$ protons, which were again confirmed by successive proton decoupling experiments. In the ${ }^{13} \mathrm{C}-\mathrm{NMR}$ spectrum, the $\mathrm{C}-2$ carbon signal appeared at $\delta 39.0$.

Similarly, the 2- and 4-thionocarbonate diacetates, (7b) and (8b), of methyl $\alpha$-Dxylopyranoside (6) and the 4-thionocarbonate diacetate (12b) of methyl $\beta$-D-xylopyranoside (11) were deoxygenated to the corresponding deoxy derivatives in the yields given in Table II. The structures of these products were also confirmed by analyses of the ${ }^{1} \mathrm{H}$ - and ${ }^{13} \mathrm{C}-\mathrm{NMR}$ spectra (Table IV).

The secondary thionocarbonates were smoothly reduced to the corresponding deoxy derivatives. However, the primary thionocarbonates produced the deoxy compounds in poor 
TABLE II. Yields and Percentage Compositions of the Mono-thionocarbonates and the Deoxy Derivatives of the Glycopyranosides That Do Not

Have a cis-Vicinal Glycol System

\begin{tabular}{|c|c|c|c|c|c|}
\hline \multirow{4}{*}{$\begin{array}{r}\begin{array}{r}\text { Starting } \\
\text { material }\end{array} \\
\text { Me } \alpha \text {-D-Glc }(\mathbf{1})\end{array}$} & \multicolumn{3}{|c|}{ Mono-thionocarbonate } & \multirow{2}{*}{\multicolumn{2}{|c|}{$\begin{array}{c}\text { Deoxy derivatives } \\
\text { Yield }(\%)\end{array}$}} \\
\hline & \multirow{2}{*}{$\frac{\text { Yield }(\%)}{83.0}$} & \multicolumn{2}{|c|}{ Composition $^{a)}$} & & \\
\hline & & 2-Ester $(\mathbf{2 a})$ & 93.5 & 2-Deoxy $(\mathbf{2 2 b})$ & 75.6 \\
\hline & & 6-Ester (3) & 6.5 & - & \\
\hline Me $\beta$-D-Glc (4) & 84.8 & 6-Ester (5) & 100.0 & - & \\
\hline \multirow[t]{2}{*}{$\operatorname{Me} \alpha-D-X y l(6)$} & 76.3 & 2-Ester (7a) & 54.0 & 2-Deoxy (23) & 91.6 \\
\hline & & 4-Ester (8a) & 46.0 & 4-Deoxy (24) & 83.2 \\
\hline Me $\beta$-D-Xyl (11) & 97.4 & 4 -Ester (12a) & 100.0 & 4-Deoxy (25) & 82.6 \\
\hline
\end{tabular}

a) Composition was determined by measuring the OMe peak areas in the ${ }^{1} \mathrm{H}-\mathrm{NMR}$ spectra.

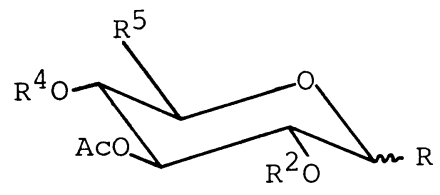

2b: $\quad \mathrm{R}^{4}=\mathrm{Ac}, \mathrm{R}^{5}=\mathrm{CH}_{2} \mathrm{OAc}, \mathrm{R}^{2}=$ PhOCS,$- \mathrm{R}=\alpha-\mathrm{OMe}$

$7 \mathrm{~b}: \quad \mathrm{R}^{4}=\mathrm{Ac}, \mathrm{R}^{5}=\mathrm{H}, \mathrm{R}^{2}=$ PhOCS,$- \quad \mathrm{R}=\alpha-\mathrm{OMe}$

8b: $\quad R^{2}=A c, R^{5}=H, R^{4}=$ PhOCS-,$R=\alpha-O M e$

12b : $\quad \mathrm{R}^{2}=\mathrm{Ac}, \mathrm{R}^{5}=\mathrm{H}, \mathrm{R}^{4}=\mathrm{PhOCS}^{-}, \quad \mathrm{R}=\beta-\mathrm{OMe}$
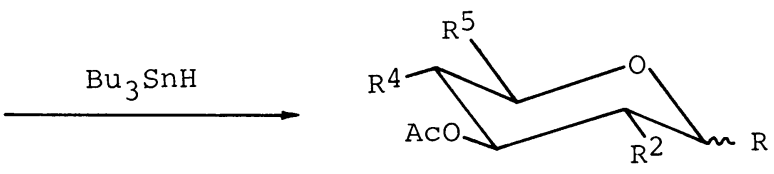

Chart 5

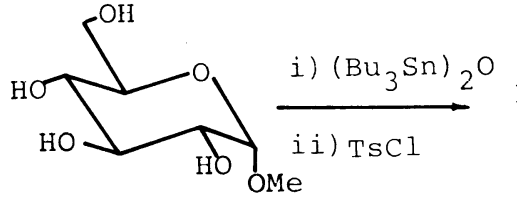

1

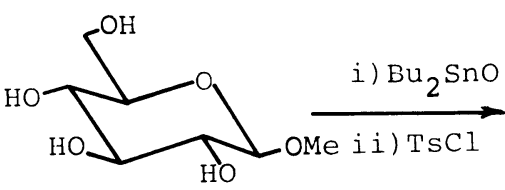

4

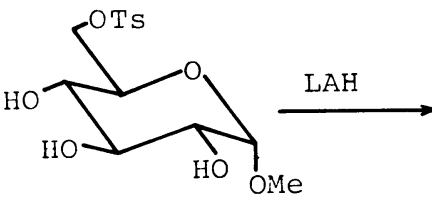

26 22b: $\quad \mathrm{R}^{4}=\mathrm{OAc}, \mathrm{R}^{5}=\mathrm{CH}_{2} \mathrm{OAc}, \mathrm{R}^{2}=\mathrm{H}, \mathrm{R}=\alpha-\mathrm{OMe}$

23: $\mathrm{R}^{4}=\mathrm{OAc}, \mathrm{R}^{2}=\mathrm{R}^{5}=\mathrm{H}, \mathrm{R}=\alpha-\mathrm{OMe}$

24: $\quad \mathrm{R}^{2}=\mathrm{OAc}, \mathrm{R}^{4}=\mathrm{R}^{5}=\mathrm{H}, \mathrm{R}=\alpha-\mathrm{OMe}$

25: $\quad \mathrm{R}^{2}=\mathrm{OAc}, \mathrm{R}^{4}=\mathrm{R}^{5}=\mathrm{H}, \mathrm{R}=\beta$-OMe

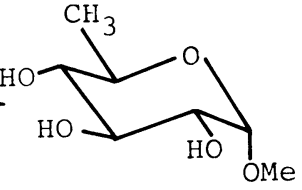

27

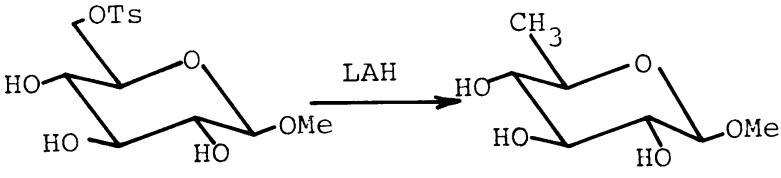

28

29

Chart 6

yields [for example, the 6-thionocarbonates of $\alpha$ - and $\beta$-D-glucopyranoside ( 3 and $\mathbf{5}$ ) and methyl $\alpha$-D-galactopyranoside (17)], clearly because of the lesser stability of the primary relative to the secondary carbon radical. ${ }^{8)}$

On the other hand, primary tosylates undergo smooth deoxygenation with an excess of lithium aluminum hydride (LAH) in refluxing tetrahydrofuran (THF). Thus, tosylation of methyl $\alpha$-D-glucopyranoside $(\mathbf{1})$ by using the $\left(\mathrm{Bu}_{3} \mathrm{Sn}\right)_{2} \mathrm{O}$ method, ${ }^{3)}$ gave the 6-tosylate $(\mathbf{2 6})$ as the major product, which on reduction with an excess of LAH gave the corresponding 6deoxy compound (27) in $71 \%$ yield. Tosylation of methyl $\beta$-D-glucopyranoside (4) by using the $\mathrm{Bu}_{2} \mathrm{SnO}$ method produced the 6-tosylate (28) in $92.4 \%$ yield, and this was also reduced to 
the corresponding 6-deoxy compound in 68\% yield. These 6-deoxy compounds were characterized by analyses of their ${ }^{1} \mathrm{H}$ - and ${ }^{13} \mathrm{C}-\mathrm{NMR}$ spectra.

The cyclic thionocarbonates, produced from the pyranosides with a cis-vicinal glycol, undergo radical deoxygenation by $\mathrm{Bu}_{3} \mathrm{SnH}$, but in these cases two deoxy compounds were formed, thus reducing the yield as well as the selectivity of deoxygenation. By using this method, the 3,4-cyclic thionocarbonate acetates of methyl $\alpha$ - and $\beta$-D-galactopyranosides were deoxygenated to the corresponding 3- and 4-deoxy derivatives in the yields shown in Table III. The products were identified and characterized by analyses of their ${ }^{1} \mathrm{H}$ - and ${ }^{13} \mathrm{C}$ NMR spectra.

3,4-Cyclic thionocarbonate acetates of pentopyranosides, such as phenyl $\alpha$-L-

TABle III. Yields and Percentage Compositions of the Cyclic Thionocarbonates, Deoxy, Unsaturated, and Dideoxy Derivatives of the Pyranosides Which Possess a cis-Vicinal Glycol System

\begin{tabular}{|c|c|c|c|c|}
\hline $\begin{array}{l}\text { Starting } \\
\text { material }\end{array}$ & $\begin{array}{c}\text { 3,4-Thionocarbonate } \\
\text { Yield }(\%)\end{array}$ & $\begin{array}{c}\text { Deoxy compound } \\
\text { Yield }(\%) \text { 3-Deoxy : 4-Deoxy }\end{array}$ & $\begin{array}{l}\text { Unsaturated } \\
\text { compound } \\
\text { Yield }(\%)\end{array}$ & $\begin{array}{c}\text { Dideoxy } \\
\text { compound } \\
\text { Yield }(\%)\end{array}$ \\
\hline Me $\beta$-D-Gal (13) & (14a) 85.3 & $56.0 \quad$ (30) $57:$ (31) 43 & (41b) 65.6 & $(42)(96)$ \\
\hline Me $\alpha$-D-Gal (15) & (16a) 62.6 & $56.6 \quad$ (32) $67:$ (33) 33 & (43b) 55.1 & (44) 100 \\
\hline $\mathrm{Ph} \alpha$-L-Ara & (19a) 94.9 & $73.6 \quad$ (34) $74:(35) 26$ & (45b) 75.6 & (46) 99 \\
\hline Me $\beta$-L-Ara (20) & (21a) 83.2 & 57.3 (36) $50:$ (37) 50 & $(47 b) 64.8$ & (48) 99 \\
\hline
\end{tabular}
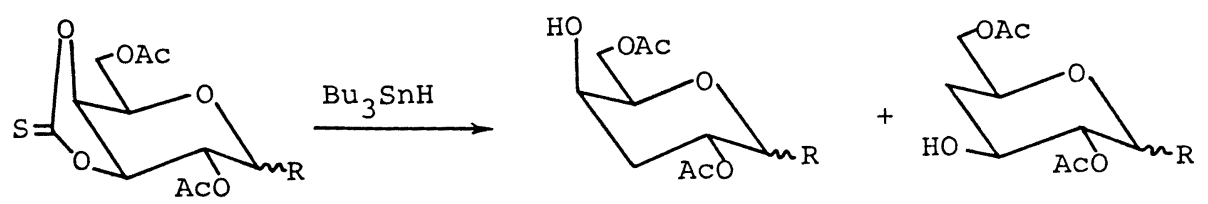

$14 b: R=\beta-O M e$

$30: R=\beta-O M e$

$31: \mathrm{R}=\beta-\mathrm{OMe}$

$16 \mathrm{~b}: \mathrm{R}=\alpha-\mathrm{OMe}$

$32: \mathrm{R}=\alpha-\mathrm{OMe}$

$33: \mathrm{R}=\alpha-\mathrm{OMe}$

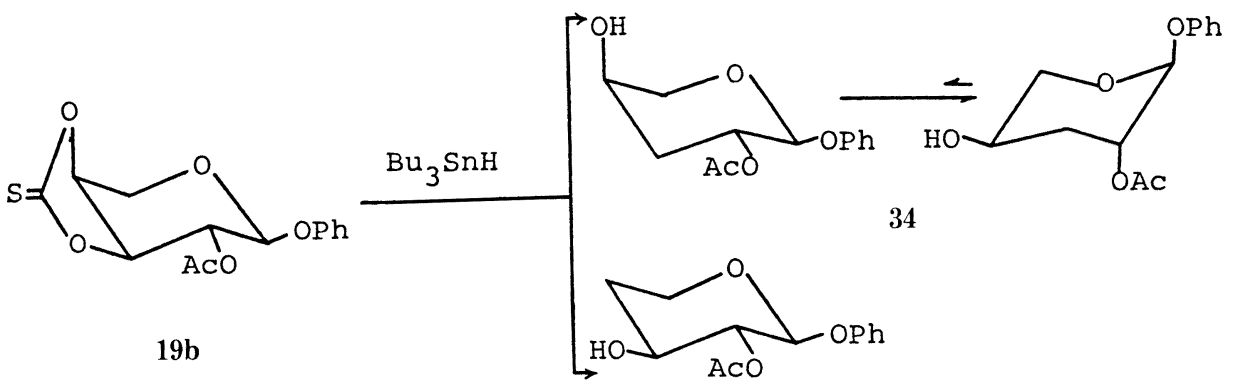

35<smiles>CO[C@H]1O[C@@H]2CO[C@@H](CO2)[C@H]1OC</smiles>

$21 b$

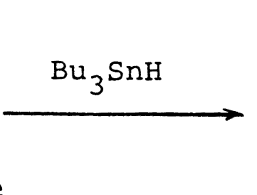$$
\text { (1) }
$$ 
arabinopyranoside (18) and methyl $\beta$-L-arabinopyranoside (20) also undergo similar deoxygenation to give the corresponding 3- and 4-deoxy derivatives in the yields given in Table III. From the ${ }^{1} \mathrm{H}$-NMR spectra the 3 -deoxy derivative (34) of phenyl $\alpha$-L-arabinopyranoside was found to be in the $1 C$ conformation, since its anomeric proton signal appeared at $\delta 5.71$ as a doublet with $J=2.5 \mathrm{~Hz}$. Spectral data for the deoxy sugars are listed in Table IV.

It should be noted that when this deoxygenation reaction was carried out at a higher temperature and/or a higher concentration of the reagent, undesired side reactions were observed. For example, when $\mathbf{2 1 b}$ was treated with an excess of $\mathrm{Bu}_{3} \mathrm{SnH}(5 \mathrm{~mol} \mathrm{eq})$ at $100^{\circ} \mathrm{C}$, the methylidene derivative (38) and a compound tentatively assigned as $39, \mathrm{mp} 117-119^{\circ} \mathrm{C}$, were the major products. The reaction with $1.5 \mathrm{~mol}$ eq of the reagent at $100^{\circ} \mathrm{C}$ produced four products, 36, 38, 39, and $\mathbf{4 0}$, of which $\mathbf{4 0}$ is the acetyl migration product from the expected 4 deoxy derivative (37). ${ }^{9)}$ The best result was obtained by the reaction of $21 \mathbf{b}$ with $1.5 \mathrm{~mol}$ eq of $\mathrm{Bu}_{3} \mathrm{SnH}$ at $75^{\circ} \mathrm{C}$, where the expected 36 and 37 were produced in a ratio of $1: 1$ with the combined yield of $56.7 \%$ (see Table III). Details of the above side reactions and the structure

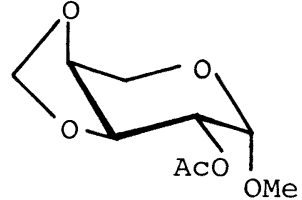

38

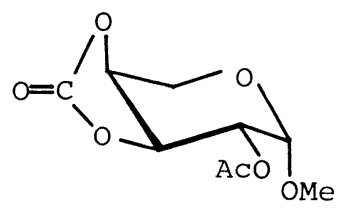

39

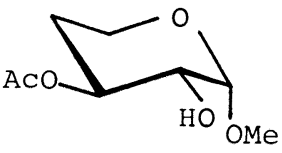

40

Chart 8

TABLE IV. ${ }^{13}$ C-Chemical Shifts of Deoxy Derivatives of Some Hexo- and Pentopyranosides in Pyridine- $d_{5}$

\begin{tabular}{|c|c|c|c|c|c|c|c|c|c|}
\hline Deoxy sugars of & $\mathrm{C}-1$ & $C-2$ & $\mathrm{C}-3$ & $\mathrm{C}-4$ & $C-5$ & C-6 & $\mathrm{OMe}$ & $\mathrm{CH}_{3}$ & $\mathrm{C}=\mathrm{O}$ \\
\hline \multicolumn{10}{|l|}{ 2-Deoxy sugars of } \\
\hline Me $\alpha$-D-Glc (22b) & 99.2 & 39.0 & 69.5 & $74.4^{a)}$ & $73.6^{a)}$ & 62.9 & 54.4 & & \\
\hline \multirow[t]{2}{*}{ Me $\alpha$-D-Xyl 3,4-diAc (23) } & 98.5 & 34.9 & $68.8^{a)}$ & $69.9^{a)}$ & 59.8 & & 54.8 & 20.7 & 160.9 \\
\hline & & & & & & & & 20.9 & 170.1 \\
\hline \multicolumn{10}{|l|}{ 3-Deoxy sugars of } \\
\hline \multirow[t]{2}{*}{ Me $\alpha$-D-Gal 2,6-diAc (32) } & 97.3 & 67.7 & 32.3 & 66.1 & 69.2 & 64.8 & 54.8 & 20.7 & 170.4 \\
\hline & & & & & & & & 20.9 & 170.7 \\
\hline \multirow[t]{2}{*}{ Me $\beta$-D-Gal 2,6-diAc (30) } & 103.7 & 68.7 & 36.6 & 65.6 & 76.4 & 64.5 & 56.0 & 21.0 & 169.7 \\
\hline & & & & & & & & 21.7 & 169.9 \\
\hline Ph $\alpha$-L-Ara 2-Ac (34) & 95.1 & 70.2 & 33.6 & 66.2 & 61.6 & & & 20.9 & 170.1 \\
\hline Me $\beta$-L-Ara 2 -Ac (36) & 97.9 & 68.1 & 32.0 & 65.9 & 64.8 & & 55.1 & 21.0 & 170.3 \\
\hline \multicolumn{10}{|l|}{ 4-Deoxy sugars of } \\
\hline \multirow[t]{2}{*}{$\mathrm{Me} \alpha$-D-Gal 2,6-diAc (33) } & 98.4 & 76.9 & 65.0 & 36.8 & 66.4 & 66.3 & 54.9 & 20.7 & 170.5 \\
\hline & & & & & & & & 20.9 & 170.8 \\
\hline \multirow[t]{2}{*}{ Me $\beta$-D-Gal 2,6-diAc (31) } & 102.5 & 76.7 & $70.4^{a)}$ & 36.6 & $69.3^{a)}$ & 66.1 & 56.2 & 20.6 & 170.1 \\
\hline & & & & & & & & 21.0 & 170.4 \\
\hline \multirow[t]{2}{*}{ Me $\alpha$-D-Xyl 2,3-diAc (24) } & 98.3 & 72.8 & 68.2 & 31.3 & 57.3 & & 55.0 & 20.7 & 170.1 \\
\hline & & & & & & & & 20.8 & 170.4 \\
\hline \multirow[t]{2}{*}{ Me $\beta$-D-Xyl 2,3-diAc (25) } & 102.1 & 72.2 & 70.9 & 30.3 & 60.2 & & 56.2 & 20.8 & 169.8 \\
\hline & & & & & & & & 20.8 & 170.2 \\
\hline Ph $\alpha$-L-Ara 2-Ac (35) & 100.2 & 76.3 & 69.3 & 34.0 & 61.7 & & & 20.9 & 170.1 \\
\hline Me $\beta$-L-Ara 2-Ac (37) & 98.7 & 76.9 & 65.3 & 34.9 & 58.3 & & 55.0 & 21.0 & 170.8 \\
\hline Me $\beta$-L-Ara 3-Ac (40) & 101.6 & 71.6 & 71.6 & 31.2 & 57.5 & & 55.0 & 20.9 & 170.5 \\
\hline \multicolumn{10}{|l|}{ 6-Deoxy sugars of } \\
\hline Me $\alpha$-D-Glc (27) & 101.4 & 74.0 & 75.1 & 77.4 & 68.5 & 18.6 & 55.0 & & \\
\hline Me $\beta$-D-Glc (29) & 105.4 & 75.2 & 78.2 & 72.9 & 76.8 & 18.6 & 56.6 & & \\
\hline
\end{tabular}

a) Assignments may be interchanged in each row. 
determinations of the by-products will be presented in a separate paper.

\section{Olefination and Hydrogenation}

The acetates of the cyclic thionocarbonates synthesized in a foregoing section undergo olefination according to the Corey-Winter method, ${ }^{10)}$ to produce the unsaturated sugars in satisfactory yields. Thus the 3,4-cyclic thionocarbonate 2,6-diacetate (14b) of methyl $\beta$-Dgalactopyranoside, when heated under reflux in trimethylphosphite, gave the corresponding unsaturated derivative (41b) $(65.6 \%)$ as colorless needles, mp $78-80 \mathrm{C}$. In the ${ }^{1} \mathrm{H}-\mathrm{NMR}$ spectrum it showed low-field signals at $\delta 5.91(1 \mathrm{H}$, ddd, $J=1.2,1.8$, and $10.4 \mathrm{~Hz})$ due to $\mathrm{H}-3$ and at $\delta 5.85(1 \mathrm{H}$, ddd, $J=2.4,3.0$, and $10.4 \mathrm{~Hz})$ due to $\mathrm{H}-4$, confirming the presence of a double bond between the 3- and 4-positions. Moreover, in the ${ }^{13} \mathrm{C}-\mathrm{NMR}$ spectrum two lowfield signals due to C-3 and C-4 appeared at $\delta 129.2$ and 124.7, respectively (Table V). Deacetylation with $\mathrm{NaOMe}$ in $\mathrm{MeOH}$ followed by hydrogenation over $\mathrm{PtO}_{2}$ in $\mathrm{MeOH}$ produced the 3,4-dideoxy derivative (42) quantitatively. This compound showed four highfield proton signals due to $\mathrm{H}_{2}-3$ and $\mathrm{H}_{2}-4$ between $\delta 1.45$ to 2.12 as multiplets, and in the ${ }^{13} \mathrm{C}$ NMR spectrum the C-3 and C-4 carbon signals appeared at $\delta 29.0$ and 26.0, respectively (Table V).

The 3,4-cyclic thionocarbonate 2,6-diacetate (16b) of methyl $\alpha$-D-galactopyranoside also produced the unsaturated compound $(\mathbf{4 3 b})$ in $55.1 \%$ yield. The site of unsaturation between C-3 and C-4 was confirmed by analysis of the ${ }^{1} \mathrm{H}-\mathrm{NMR}$ spectrum and from ${ }^{1} \mathrm{H}-{ }^{13} \mathrm{C}$ shift correlation studies. This compound (43b) on deacetylation followed by hydrogenation gave the 3,4-dideoxy compound (44) quantitatively.

The 3,4-cyclic thionocarbonate acetates of pentopyranosides, such as phenyl $\alpha$-Larabinopyranoside (19b) and methyl $\beta$-L-arabinopyranoside (21b), undergo similar olefina-

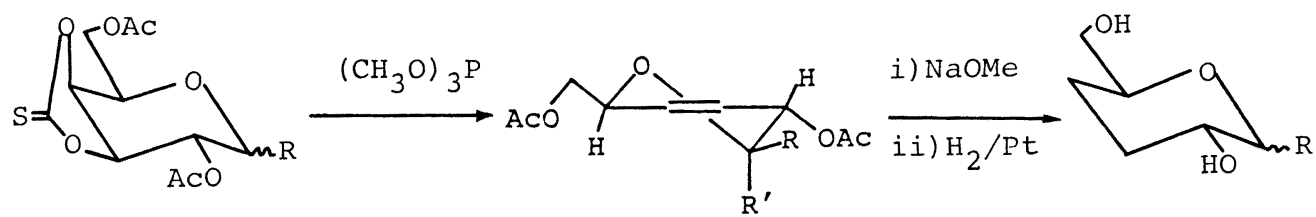
$14 b: R=\beta-O M e$
$41 \mathrm{~b}: \mathrm{R}=\mathrm{OMe}, \mathrm{R}^{\prime}=\mathrm{H}$
$42: \mathrm{R}=\beta-\mathrm{OMe}$
$16 \mathrm{~b}: \mathrm{R}=\alpha-\mathrm{OMe}$
43b : $\mathrm{R}=\mathrm{H}, \mathrm{R}^{\prime}=\mathrm{OMe}$
$44: \mathrm{R}=\alpha-\mathrm{OMe}$

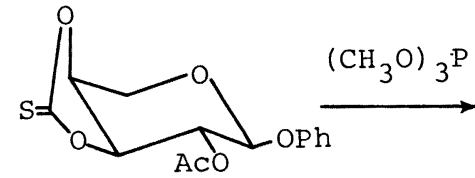

$19 b$

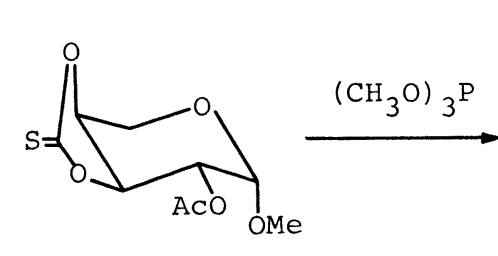

$21 b$

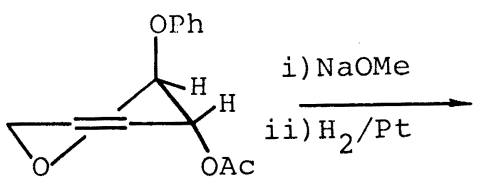

$45 \mathrm{~b}$

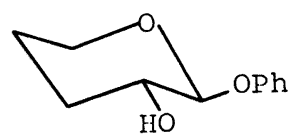

46
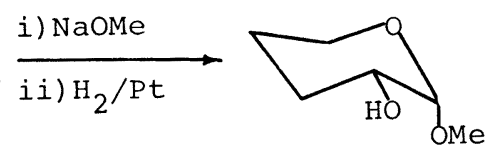

Chart 9 
TABLE V. ${ }^{13}$ C-NMR Chemical Shifts of Some Unsaturated Glycopyranosides and Their Dideoxy Derivatives in $\mathrm{CDCl}_{3}$

\begin{tabular}{|c|c|c|c|c|c|c|c|c|c|c|}
\hline Compounds & & $\mathrm{C}-1$ & $C-2$ & $\mathrm{C}-3$ & $C-4$ & $C-5$ & $C-6$ & $\mathrm{OMe}$ & $\mathrm{Me}$ & $\mathrm{C}=\mathrm{O}$ \\
\hline \multicolumn{11}{|l|}{ Me $\beta$-D-Gal } \\
\hline 3-Enoside, 2,6-diAc & $(41 b)$ & 100.1 & 67.3 & 129.2 & 124.7 & 71.6 & 65.9 & 56.2 & 21.0 & 170.0 \\
\hline 3-Enoside & (41a) & 103.7 & 66.9 & 128.4 & 127.6 & 75.5 & 65.0 & 56.7 & 20.8 & 170.1 \\
\hline 3,4-Dideoxy & (42) & 106.4 & 69.8 & 29.0 & 26.0 & 76.5 & 65.2 & 56.9 & & \\
\hline \multicolumn{11}{|l|}{ Me $\alpha$-D-Gal } \\
\hline 3-Enoside, 2,6-diAc & $(43 b)$ & 95.9 & 66.7 & 127.9 & 124.3 & 66.5 & 65.3 & 56.0 & 20.9 & 170.7 \\
\hline 3-Enoside & $(43 a)$ & 98.2 & 64.3 & 128.9 & 126.4 & 69.0 & 64.9 & 56.1 & 20.8 & 170.4 \\
\hline 3,4-Dideoxy & (44) & 99.4 & 68.2 & 27.1 & 26.0 & 68.5 & 65.5 & 55.1 & & \\
\hline \multicolumn{11}{|l|}{$\mathrm{Ph} \alpha$-L-Ara } \\
\hline 3-Enoside, 2-Ac & $(45 b)$ & 95.9 & 65.8 & 131.4 & 120.1 & 59.8 & & & 21.0 & 170.2 \\
\hline 3-Enoside & (45a) & 98.6 & 64.5 & 129.3 & 124.2 & 60.9 & & & & \\
\hline 3,4-Dideoxy & $(46)$ & 100.8 & 68.0 & 27.7 & 22.3 & 63.5 & & & & \\
\hline \multicolumn{11}{|l|}{ Me $\beta$-L-Ara } \\
\hline 3-Enoside, 2-Ac & $(47 b)$ & 96.1 & 66.5 & 129.3 & 121.8 & 60.2 & & 56.1 & 21.0 & 170.6 \\
\hline 3-Enoside & $(47 a)$ & 98.1 & 64.2 & 129.0 & 127.0 & 60.0 & & 56.1 & & \\
\hline 3,4-Dideoxy & $(48)$ & 99.7 & 68.0 & 27.5 & 24.0 & 59.5 & & 55.1 & & \\
\hline
\end{tabular}

tion to produce the corresponding unsaturated derivatives (45b and $47 \mathbf{b}$ ) in 75.6 and $64.8 \%$ yields, respectively. In both cases, the site of unsaturation was between the C-3 and C-4 positions. Compound $\mathbf{4 5 b}$ was found to be in the ${ }^{1} H_{\mathrm{O}}$ conformation, since the anomeric proton signal appeared at $\delta 5.56$ as a broad singlet in the ${ }^{1} \mathrm{H}-\mathrm{NMR}$ spectrum. On deacetylation followed by hydrogenation, $\mathbf{4 5 b}$ and $\mathbf{4 7 b}$ gave the corresponding dideoxy derivatives 46 and 48 quantitatively, as confirmed by analyses of their ${ }^{1} \mathrm{H}$ - and ${ }^{13} \mathrm{C}-\mathrm{NMR}$ spectra. From the ${ }^{1} \mathrm{H}-\mathrm{NMR}$ spectrum, 46 was found to be in the $C 1$ conformation, since its anomeric proton signal appeared at $\delta 5.03$ as a doublet with $J=5.2 \mathrm{~Hz}$.

\section{Conclusion}

The glycopyranosides whose hydroxyl groups are all trans oriented are regioselectively mono-thioacylated by the $\mathrm{Bu}_{2} \mathrm{SnO}$ method and are deoxygenated to the corresponding deoxy derivatives in high yields. In the cases of pyranosides which possess a cis-vicinal glycol system, this method produces the cyclic thionocarbonates, which are smoothly deoxygenated to the dideoxy sugars through the unsaturated derivatives. The deoxy, unsaturated, and dideoxy sugars thus obtained should be useful intermediates for syntheses of complex molecules having chiral centers.

\section{Experimental}

Melting points were determined on a Yanaco micro hot stage melting point apparatus and are uncorrected. Infrared (IR) spectra were recorded in $\mathrm{KBr}$ discs on a Jasco IRA-2 spectrometer and the data are given in $\mathrm{cm}^{-1}$. Unless otherwise stated, ${ }^{1} \mathrm{H}-\mathrm{NMR}(400 \mathrm{MHz})$ spectra and ${ }^{13} \mathrm{C}-\mathrm{NMR}$ spectra $(100 \mathrm{MHz})$ were recorded with a JEOL JNM GX400 FT NMR spectrometer in pyridine- $d_{5}$ solution with tetramethylsilane as an internal standard, and the chemical shifts are given in $\delta$ values. Concentrations were about $0.1-0.3 \mathrm{mmol} / \mathrm{ml}$. Column chromatography was performed on Wakogel C-200. For thin layer chromatography (TLC) Kieselgel $60 \mathrm{~F}_{254}$ precoated plates were used and spots were developed by spraying $1 \% \mathrm{Ce}\left(\mathrm{SO}_{4}\right)_{2}$ in $10 \% \mathrm{H}_{2} \mathrm{SO}_{4}$ and heating the plates at $100 \mathrm{C}$ until coloration took place.

Thioacylation of Pyranosides (General Procedure)-Glycopyranoside $(0.3-0.9 \mathrm{mmol})$ and $\mathrm{Bu}_{2} \mathrm{SnO}(1.5 \mathrm{~mol}$ eq) in dry $\mathrm{MeOH}(10-25 \mathrm{ml})$ were heated under reflux until the mixture became homogeneous and clear $($ about $1 \mathrm{~h})$. The mixture was refluxed for an additional $2 \mathrm{~h}$, then the solvent was evaporated off in vacuo to leave a glassy solid, 
which was dissolved in dioxane $(10-25 \mathrm{ml})$. Phenoxythiocarbonyl chloride $(1.1 \mathrm{~mol}$ eq) was added dropwise to the stirred solution at room temperature. When the tin complex was insoluble in dioxane (in the cases of Me $\alpha$-D-Gal and Me $\beta$-D-Gal), it was suspended in dioxane. The mixture became clear upon addition of phenoxythiocarbonyl chloride. Maximum conversion was checked by TLC. After $1-1.5 \mathrm{~h}$, the solvent was evaporated off in vacuo to leave a syrupy residue, which was subjected to column chromatography for further separation.

Deoxygenation (General Procedure) - The mono-thionocarbonates or cyclic thionocarbonates obtained by the above procedure were acetylated with acetic anhydride and pyridine in a usual manner. The acetates $(100-300 \mathrm{mg})$ thus obtained were dissolved in toluene $(10-15 \mathrm{ml}), \mathrm{Bu}_{3} \mathrm{SnH}(1.1-1.5 \mathrm{~mol}$ eq) was added, and the mixture was heated at $75-100^{\circ} \mathrm{C}$ with the addition of catalytic amount of AIBN for $1-3.5 \mathrm{~h}$. The solvent was evaporated off in vacuo to leave a syrup, which was chromatographed for further separation and purification.

Olefination and Hydrogenation (General Procedure) - The cyclic thionocarbonate obtained by the thioacylation of the pyranosides which possesses a cis-vicinal glycol was acetylated with acetic anhydride and pyridine in a usual manner. The acetate $(20-200 \mathrm{mg})$ was dissolved in trimethyl phosphite $(3-5 \mathrm{ml})$ and heated under reflux for $70 \mathrm{~h}$. Saturated $\mathrm{Na}_{2} \mathrm{CO}_{3}$ aq. was added to the cooled mixture and the mixture was extracted with $\mathrm{CH}_{2} \mathrm{Cl}_{2}$. The organic extract was dried and concentrated in vacuo to leave a residue, which was purified by silica gel column chromatography with benzene-AcOEt. The unsaturated sugar $(30-60 \mathrm{mg})$ thus obtained was deacetylated with $0.2 \mathrm{~N}$ $\mathrm{NaOMe}(0.3-0.6 \mathrm{ml})$ in $\mathrm{MeOH}(2.5-5 \mathrm{ml})$ at room temperature for $20-30 \mathrm{~min}$. The reaction mixture was then made just neutral by adding Dowex $50 \times 8\left(\mathrm{H}^{+}\right)$and filtered. The filtrate was concentrated in vacuo to leave a residue, which was subjected to hydrogenation over $\mathrm{PtO}_{2}$ in $\mathrm{MeOH}$ for $4-5 \mathrm{~h}$ without further purification. The catalyst was removed by filtration, the filtrate was carefully concentrated in vacuo and the residue was subjected to preparative TLC.

Methyl $\boldsymbol{\alpha}$-D-Glucopyranoside 2-Phenylthionocarbonate (2a)—-Needles from AcOEt-light petroleum, mp 128 $129^{\circ} \mathrm{C} .{ }^{1} \mathrm{H}-\mathrm{NMR}(200 \mathrm{MHz}): 7.06-7.36(5 \mathrm{H}, \mathrm{m}, \mathrm{ArH}), 5.79(1 \mathrm{H}, \mathrm{dd}, J=3.9,10.0 \mathrm{~Hz}, \mathrm{H}-2), 5.51(1 \mathrm{H}, \mathrm{d}, J=3.9 \mathrm{~Hz}$, $\mathrm{H}-1), 4.37(1 \mathrm{H}, \mathrm{t}, J=10.0 \mathrm{~Hz}, \mathrm{H}-3), 3.39$ (3H, s, OMe). IR: 3400, 2900, 1040. Anal. Calcd for $\mathrm{C}_{14} \mathrm{H}_{18} \mathrm{O}_{7} \mathrm{~S}: \mathrm{C}, 50.90 ; \mathrm{H}$, 5.50. Found: $\mathrm{C}, 50.96 ; \mathrm{H}, 5.54$.

The 3,4,6-triacetate (2b) was a syrup. ${ }^{1} \mathrm{H}-\mathrm{NMR}\left(200 \mathrm{MHz}, \mathrm{CDCl}_{3}\right): 7.03-7.44(5 \mathrm{H}, \mathrm{m}, \mathrm{ArH}), 5.62(1 \mathrm{H}, \mathrm{dd}, J=$ $10.0,10.5 \mathrm{~Hz}, \mathrm{H}-3), 5.42(1 \mathrm{H}, \mathrm{dd}, J=4.0,10.0 \mathrm{~Hz}, \mathrm{H}-2), 5.18(1 \mathrm{H}, \mathrm{d}, J=4.0 \mathrm{~Hz}, \mathrm{H}-1), 5.09(1 \mathrm{H}, \mathrm{t}, J=10.5 \mathrm{~Hz}, \mathrm{H}-4)$, $4.00-4.36\left(3 \mathrm{H}, \mathrm{m}, \mathrm{H}-5\right.$ and $\left.\mathrm{H}_{2}-6\right), 3.46(3 \mathrm{H}, \mathrm{s}, \mathrm{OMe}), 2.02,2.03$, and 2.09 (3H each, s, OAc).

The 6-phenylthionocarbonate (3) was also formed, but was not isolated; it showed an OMe signal at $\delta 3.35$.

Methyl $\boldsymbol{\beta}$-D-Glucopyranoside 6-Phenylthionocarbonate (5)- - Syrup. ${ }^{1} \mathrm{H}-\mathrm{NMR}$ : $7.17-7.41$ (5H, m, ArH), 5.38 $(1 \mathrm{H}, \mathrm{dd}, J=0.8,11.4 \mathrm{~Hz}, \mathrm{H}-6), 5.17(1 \mathrm{H}, \mathrm{dd}, J=5.5,11.4 \mathrm{~Hz}, \mathrm{H}-6), 4.72(1 \mathrm{H}, \mathrm{d}, J=7.6 \mathrm{~Hz}, \mathrm{H}-1), 4.22(1 \mathrm{H}, \mathrm{t}, J=$ $8.0 \mathrm{~Hz}, \mathrm{H}-3), 4.13(2 \mathrm{H}, \mathrm{m}, \mathrm{H}-4,5), 4.01(1 \mathrm{H}, \mathrm{dd}, J=7.6,8.0 \mathrm{~Hz}, \mathrm{H}-2), 3.62(3 \mathrm{H}, \mathrm{s}, \mathrm{OMe})$. High resolution (HR) MS $m / z$ Calcd for $\mathrm{C}_{13} \mathrm{H}_{18} \mathrm{O}_{7} \mathrm{~S}: 318.0773$. Found: 318.0772 .

Methyl $\alpha$-D-Xylopyranoside 2-Phenylthionocarbonate (7a)—-Needles from hexane-AcOEt, mp 130-131 C. ${ }^{1} \mathrm{H}-\mathrm{NMR}: 7.12-7.36(5 \mathrm{H}, \mathrm{m}, \mathrm{ArH}), 5.80(1 \mathrm{H}, \mathrm{dd}, J=3.5,9.5 \mathrm{~Hz}, \mathrm{H}-2), 5.49(1 \mathrm{H}, \mathrm{d}, J=3.5 \mathrm{~Hz}, \mathrm{H}-1), 4.71(1 \mathrm{H}, \mathrm{t}, J=$ $9.5 \mathrm{~Hz}, \mathrm{H}-3), 4.27(1 \mathrm{H}, \mathrm{m}, \mathrm{H}-4), 3.95-4.08\left(2 \mathrm{H}, \mathrm{m}, \mathrm{H}_{2}-5\right), 3.38(3 \mathrm{H}, \mathrm{s}, \mathrm{OMe})$. IR: $3400,2900,1040$. Anal. Calcd for $\mathrm{C}_{13} \mathrm{H}_{16} \mathrm{O}_{6} \mathrm{~S}: \mathrm{C}, 52.00 ; \mathrm{H}, 5.37$. Found: C, 51.96; H, 5.39.

The 3,4-diacetate $(\mathbf{7 b})$ forms needles from hexane-ether, mp 139-140 C. ${ }^{1} \mathrm{H}-\mathrm{NMR}\left(\mathrm{CDCl}_{3}\right): 7.07-7.44(5 \mathrm{H}$, $\mathrm{m}, \mathrm{ArH}), 5.65(1 \mathrm{H}, \mathrm{t}, J=9.5 \mathrm{~Hz}, \mathrm{H}-3), 5.39(1 \mathrm{H}, \mathrm{dd}, J=3.7,9.5 \mathrm{~Hz}, \mathrm{H}-2), 5.14(1 \mathrm{H}, \mathrm{d}, J=3.7 \mathrm{~Hz}, \mathrm{H}-1), 5.05(1 \mathrm{H}, \mathrm{ddd}$, $J=5.8,9.5,10.7 \mathrm{~Hz}, \mathrm{H}-4), 3.84(1 \mathrm{H}, \mathrm{dd}, J=5.8,10.7 \mathrm{~Hz}, \mathrm{H}-5 \mathrm{eq}), 3.66(1 \mathrm{H}, \mathrm{t}, J=10.7 \mathrm{~Hz}, \mathrm{H}-5 \mathrm{ax}), 3.47(3 \mathrm{H}, \mathrm{s}, \mathrm{OMe})$, 2.05 and 2.08 ( $3 \mathrm{H}$ each, s, OAc). IR: 2950, 1740, 1040. Anal. Calcd for $\mathrm{C}_{17} \mathrm{H}_{20} \mathrm{O}_{8} \mathrm{~S}: \mathrm{C}, 53.12 ; \mathrm{H}, 5.25$. Found: C, 53.02; $\mathrm{H}, 5.31$.

Methyl $\boldsymbol{\alpha}$-D-Xylopyranoside 4-Phenylthionocarbonate (8a)-Needles from hexane-AcOEt, mp $115-116^{\circ} \mathrm{C}$. ${ }^{1} \mathrm{H}-\mathrm{NMR}: 7.17-7.36(5 \mathrm{H}, \mathrm{m}, \mathrm{ArH}), 5.80(1 \mathrm{H}, \mathrm{ddd}, J=5.8,9.2,10.5 \mathrm{~Hz}, \mathrm{H}-4), 5.07(1 \mathrm{H}, \mathrm{d}, J=3.5 \mathrm{~Hz}, \mathrm{H}-1), 4.67(1 \mathrm{H}$, $\mathrm{t}, J=9.2 \mathrm{~Hz}, \mathrm{H}-3), 4.26(1 \mathrm{H}, \mathrm{dd}, J=5.8,10.5 \mathrm{~Hz}, \mathrm{H}-5 \mathrm{eq}), 4.14(1 \mathrm{H}, \mathrm{dd}, J=3.5,9.2 \mathrm{~Hz}, \mathrm{H}-2), 3.83(1 \mathrm{H}, \mathrm{t}, J=10.5 \mathrm{~Hz}$, H-5ax), 3.41 (3H, s, OMe). IR: 2900, 2400, 1040. Anal. Calcd for $\mathrm{C}_{13} \mathrm{H}_{16} \mathrm{O}_{6} \mathrm{~S}: \mathrm{C}, 52.00 ; \mathrm{H}, 5.31$. Found: C, 51.99; H, 5.40 .

The 2,3-diacetate $(\mathbf{8 b})$ forms needles from hexane-AcOEt, mp 145-147 C. ${ }^{1} \mathrm{H}-\mathrm{NMR}\left(\mathrm{CDCl}_{3}\right): 7.05-7.43(5 \mathrm{H}$, $\mathrm{m}, \mathrm{ArH}), 5.67(1 \mathrm{H}, \mathrm{t}, J=9.5 \mathrm{~Hz}, \mathrm{H}-3), 5.50(1 \mathrm{H}, \mathrm{ddd}, J=6.0,9.5,10.5 \mathrm{~Hz}, \mathrm{H}-4), 4.89-4.92(2 \mathrm{H}, \mathrm{m}, \mathrm{H}-1$ and $\mathrm{H}-2)$, $4.07(1 \mathrm{H}, \mathrm{dd}, J=6.0,10.7 \mathrm{~Hz}, \mathrm{H}-5 \mathrm{eq}), 3.76(1 \mathrm{H}, \mathrm{t}, J=10.7 \mathrm{~Hz}, \mathrm{H}-5 \mathrm{ax}), 3.43(3 \mathrm{H}, \mathrm{s}, \mathrm{OMe}), 2.08$ and $2.10(3 \mathrm{H} \mathrm{each}, \mathrm{s}$, OAc). IR: 2950, 1740, 1040. Anal. Calcd for $\mathrm{C}_{17} \mathrm{H}_{20} \mathrm{O}_{8} \mathrm{~S}: \mathrm{C}, 53.12 ; \mathrm{H}, 5.25$. Found: C, 52.85; H, 5.11.

Methyl $\boldsymbol{\beta}$-D-Xylopyranoside 4-Phenylthionocarbonate (12a)- Leaflets from hexane-AcOEt, $\mathrm{mp} 136-137 \mathrm{C}$. ${ }^{1} \mathrm{H}-\mathrm{NMR}(200 \mathrm{MHz}): 7.16-7.43(5 \mathrm{H}, \mathrm{m}, \mathrm{ArH}), 5.88(1 \mathrm{H}, \mathrm{dt}, J=5.5,9.5 \mathrm{~Hz}, \mathrm{H}-4), 4.67(1 \mathrm{H}, \mathrm{d}, J=7.5 \mathrm{~Hz}, \mathrm{H}-1), 4.61$ $(1 \mathrm{H}, \mathrm{dd}, J=5.5,11.5 \mathrm{~Hz}, \mathrm{H}-5 \mathrm{eq}), 4.48(1 \mathrm{H}, \mathrm{t}, J=9.5 \mathrm{~Hz}, \mathrm{H}-3), 4.08(1 \mathrm{H}, \mathrm{dd}, J=7.5,9.5 \mathrm{~Hz}, \mathrm{H}-2), 3.71(1 \mathrm{H}, \mathrm{dd}, J=$ $9.5,11.5 \mathrm{~Hz}, \mathrm{H}-5 \mathrm{ax}), 3.59$ (3H, s, OMe). IR: $3400,2900,1040$. Anal. Calcd for $\mathrm{C}_{13} \mathrm{H}_{16} \mathrm{O}_{6} \mathrm{~S}: \mathrm{C}, 52.00 ; \mathrm{H}, 5.37$. Found: C, $52.19 ; \mathrm{H}, 5.49$.

The 2,3-diacetate (12b) forms needles from hexane-ether, mp 126-127 C. ${ }^{1} \mathrm{H}-\mathrm{NMR}\left(\mathrm{CDCl}_{3}\right): 7.07-7.44(5 \mathrm{H}$, $\mathrm{m}, \mathrm{ArH}), 5.45(1 \mathrm{H}, \mathrm{dt}, J=4.5,7.5 \mathrm{~Hz}, \mathrm{H}-4), 5.35(1 \mathrm{H}, \mathrm{t}, J=7.5 \mathrm{~Hz}, \mathrm{H}-3), 4.96(1 \mathrm{H}, \mathrm{dd}, J=6.0,7.5 \mathrm{~Hz}, \mathrm{H}-2), 4.50(1 \mathrm{H}$, d, $J=6.0 \mathrm{~Hz}, \mathrm{H}-1), 4.35(1 \mathrm{H}, \mathrm{dd}, J=4.5,12.2 \mathrm{~Hz}, \mathrm{H}-5 \mathrm{eq}), 3.62(1 \mathrm{H}, \mathrm{dd}, J=7.5,12.2 \mathrm{~Hz}, \mathrm{H}-5 \mathrm{ax}), 3.49(3 \mathrm{H}, \mathrm{s}, \mathrm{OMe})$, $2.09(6 \mathrm{H}, \mathrm{s}, \mathrm{OAc} \times 2)$. IR: 2950, 1740, 1040. Anal. Calcd for $\mathrm{C}_{17} \mathrm{H}_{20} \mathrm{O}_{8} \mathrm{~S}: \mathrm{C}, 53.12 ; \mathrm{H}, 5.25$. Found: C, 52.87; H, 5.30. 
Methyl $\boldsymbol{\beta}$-D-Galactopyranoside 3,4-Thionocarbonate (14a)-Syrup. ${ }^{1} \mathrm{H}-\mathrm{NMR}: 5.57(\mathrm{H}, \mathrm{dd}, J=2.0,7.5 \mathrm{~Hz}, \mathrm{H}$ 4), $5.48(1 \mathrm{H}, \mathrm{dd}, J=6.0,7.5 \mathrm{~Hz}, \mathrm{H}-3), 4.78(1 \mathrm{H}, \mathrm{d}, J=7.0 \mathrm{~Hz}, \mathrm{H}-1), 4.51(1 \mathrm{H}, \mathrm{dt}, J=2.0,8.0 \mathrm{~Hz}, \mathrm{H}-5), 4.30-4.34(2 \mathrm{H}$, $\left.\mathrm{m}, \mathrm{H}_{2}-6\right), 4.21(1 \mathrm{H}, \mathrm{dd}, J=6.0,7.0 \mathrm{~Hz}, \mathrm{H}-2), 3.51(3 \mathrm{H}, \mathrm{s}, \mathrm{OMe})$.

The 2,6-diacetate (14b) forms needles from benzene-AcOEt, mp 94-96 C. ${ }^{1} \mathrm{H}-\mathrm{NMR}\left(\mathrm{CDCl}_{3}\right): 4.97-5.15(3 \mathrm{H}$, $\mathrm{m}, \mathrm{H}-2,3,4), 4.75(1 \mathrm{H}$, br d, $J=c a .6 .0 \mathrm{~Hz}, \mathrm{H}-1), 4.44(1 \mathrm{H}, \mathrm{dd}, J=6.4,11.5 \mathrm{~Hz}, \mathrm{H}-6), 4.31(1 \mathrm{H}, \mathrm{dd}, J=6.4,11.5 \mathrm{~Hz}$, H-6), $4.18(1 \mathrm{H}, \mathrm{dt}, J=2.0,6.4 \mathrm{~Hz}, \mathrm{H}-5), 3.45$ (3H, s, OMe), 2.12 and 2.14 (3H each, s, OAc). IR: 1810, $1740,1040$. Anal. Calcd for $\mathrm{C}_{12} \mathrm{H}_{16} \mathrm{O}_{8} \mathrm{~S}: \mathrm{C}, 45.00 ; \mathrm{H}, 5.04$. Found: C, 45.45; H, 5.10.

Methyl $\alpha$-D-Galactopyranoside 3,4-Thionocarbonate (16a) - Syrup. ${ }^{1} \mathrm{H}-\mathrm{NMR}: 5.52-5.57(1 \mathrm{H}, \mathrm{m}, \mathrm{H}-4), 5.50$ $(1 \mathrm{H}, \mathrm{t}, J=7.0 \mathrm{~Hz}, \mathrm{H}-3), 5.20(1 \mathrm{H}, \mathrm{d}, J=4.0 \mathrm{~Hz}, \mathrm{H}-1), 4.56(1 \mathrm{H}, \mathrm{dt}, J=2.0,7.0 \mathrm{~Hz}, \mathrm{H}-5), 4.31(1 \mathrm{H}, \mathrm{dd}, J=4.0,7.0 \mathrm{~Hz}$, $\mathrm{H}-2), 4.24-4.28\left(2 \mathrm{H}, \mathrm{m}, \mathrm{H}_{2}-6\right), 3.42(3 \mathrm{H}, \mathrm{s}, \mathrm{OMe})$.

The 2,6-diacetate $(\mathbf{1 6 b})$ forms needles from hexane $-\mathrm{CH}_{2} \mathrm{Cl}_{2}, \mathrm{mp} 131-132 \mathrm{C} .{ }^{1} \mathrm{H}-\mathrm{NMR}\left(\mathrm{CDCl}_{3}\right): 5.07(1 \mathrm{H}, \mathrm{t}$, $J=7.0 \mathrm{~Hz}, \mathrm{H}-3), 5.02(1 \mathrm{H}, \mathrm{d}, J=3.7 \mathrm{~Hz}, \mathrm{H}-1), 4.94-4.98(2 \mathrm{H}, \mathrm{m}, \mathrm{H}-2$ and $\mathrm{H}-4), 4.42(1 \mathrm{H}, \mathrm{dd}, J=7.0,11.5 \mathrm{~Hz}, \mathrm{H}-6)$, $4.37(1 \mathrm{H}, \mathrm{dd}, J=6.0,11.5 \mathrm{~Hz}, \mathrm{H}-6), 4.23(1 \mathrm{H}, \mathrm{ddd}, J=2.5,6.0,7.0 \mathrm{~Hz}, \mathrm{H}-5), 3.42(3 \mathrm{H}, \mathrm{s}, \mathrm{OMe}), 2.12$ and $2.16(3 \mathrm{H}$ each, s, OAc). IR: $1720,1140,1020$. Anal. Calcd for $\mathrm{C}_{12} \mathrm{H}_{16} \mathrm{O}_{8} \mathrm{~S}: \mathrm{C}, 45.00 ; \mathrm{H}, 5.04$. Found: C, 44.82; $\mathrm{H}, 5.00$.

The 6-phenylthionocarbonate (17) was also formed, but was not isolated; it showed an OMe signal at $\delta 3.47$.

Phenyl $\alpha$-L-Arabinopyranoside 3,4-Thionocarbonate (19a) - Needles from AcOEt, mp 202-203 $\mathrm{C}$. ${ }^{1} \mathrm{H}-\mathrm{NMR}$ : $6.99-7.35(5 \mathrm{H}, \mathrm{m}, \mathrm{ArH}), 5.60(1 \mathrm{H}, \mathrm{d}, J=6.0 \mathrm{~Hz}, \mathrm{H}-1), 5.52(1 \mathrm{H}, \mathrm{dd}, J=6.0,8.0 \mathrm{~Hz}, \mathrm{H}-3), 5.40(1 \mathrm{H}, \mathrm{ddd}, J=2.5,3.0$, $8.5 \mathrm{~Hz}, \mathrm{H}-4), 4.55(1 \mathrm{H}, \mathrm{t}, J=6.0 \mathrm{~Hz}, \mathrm{H}-2), 4.50(1 \mathrm{H}, \mathrm{dd}, J=2.5,14.0 \mathrm{~Hz}, \mathrm{H}-5 \mathrm{eq}), 4.30(1 \mathrm{H}, \mathrm{dd}, J=3.0,14.0 \mathrm{~Hz}, \mathrm{H}-$ 5ax). IR: 3350, 2950, 1080. Anal. Calcd for $\mathrm{C}_{12} \mathrm{H}_{12} \mathrm{O}_{5} \mathrm{~S}: \mathrm{C}, 53.73 ; \mathrm{H}, 4.51$. Found: C, 53.97; $\mathrm{H}, 4.55$.

The 2-acetate (19b) forms needles from hexane-ether- $\mathrm{CH}_{2} \mathrm{Cl}_{2}, \mathrm{mp} 118-120{ }^{\circ} \mathrm{C} .{ }^{1} \mathrm{H}-\mathrm{NMR}\left(\mathrm{CDCl}_{3}\right): 7.00-7.34$ $(5 \mathrm{H}, \mathrm{m}, \mathrm{ArH}), 5.43(1 \mathrm{H}, \mathrm{d}, J=4.0 \mathrm{~Hz}, \mathrm{H}-1), 5.33(1 \mathrm{H}, \mathrm{t}, J=4.0 \mathrm{~Hz}, \mathrm{H}-2), 5.11(1 \mathrm{H}, \mathrm{dd}, J=4.0,8.0 \mathrm{~Hz}, \mathrm{H}-4), 5.02(1 \mathrm{H}$, dd, $J=4.0,8.0 \mathrm{~Hz}, \mathrm{H}-3), 4.24(1 \mathrm{H}$, dd, $J=4.0,14.0 \mathrm{~Hz}, \mathrm{H}-5), 4.04(1 \mathrm{H}, \mathrm{dd}, J=4.0,14.0 \mathrm{~Hz}, \mathrm{H}-5)$. IR: 2950,1740 , 1040. Anal. Calcd for $\mathrm{C}_{14} \mathrm{H}_{14} \mathrm{O}_{6} \mathrm{~S}$ : C, 54.19; H, 4.55. Found: C, 53.89; H, 4.57.

Methyl $\boldsymbol{\beta}$-L-Arabinopyranoside 3,4-Thionocarbonate (21a)-Syrup. ${ }^{1} \mathrm{H}$-NMR: $5.38(1 \mathrm{H}, \mathrm{t}, J=7.0 \mathrm{~Hz}, \mathrm{H}-3)$, $5.21(1 \mathrm{H}, \mathrm{dd}, J=2.5,7.0 \mathrm{~Hz}, \mathrm{H}-4), 4.96(1 \mathrm{H}, \mathrm{d}, J=3.4 \mathrm{~Hz}, \mathrm{H}-1), 4.32(1 \mathrm{H}, \mathrm{dd}, J=3.4,7.0 \mathrm{~Hz}, \mathrm{H}-2), 4.17(1 \mathrm{H}, \mathrm{d}, J=$ $14.0 \mathrm{~Hz}, \mathrm{H}-5 \mathrm{eq}), 4.06(1 \mathrm{H}, \mathrm{dd}, J=2.5,14.0 \mathrm{~Hz}, \mathrm{H}-5 \mathrm{ax}), 3.36(3 \mathrm{H}, \mathrm{s}, \mathrm{OMe})$.

The 2-acetate (21b) forms needles from hexane-AcOEt, mp 120-121 C. ${ }^{1} \mathrm{H}-\mathrm{NMR}\left(\mathrm{CDCl}_{3}\right): 5.05(1 \mathrm{H}, \mathrm{t}, J=$ $7.3 \mathrm{~Hz}, \mathrm{H}-3), 4.98(1 \mathrm{H}, \mathrm{d}, J=3.7 \mathrm{~Hz}, \mathrm{H}-1), 4.95(1 \mathrm{H}, \mathrm{dd}, J=2.7,7.3 \mathrm{~Hz}, \mathrm{H}-4), 4.92(1 \mathrm{H}, \mathrm{dd}, J=3.7,7.3 \mathrm{~Hz}, \mathrm{H}-2), 4.20$ $(1 \mathrm{H}, \mathrm{d}, J=14.3 \mathrm{~Hz}, \mathrm{H}-5 \mathrm{eq}), 3.96(1 \mathrm{H}, \mathrm{dd}, J=2.7,14.3 \mathrm{~Hz}, \mathrm{H}-5 \mathrm{ax}), 3.42$ (3H, s, OMe), 2.16 (3H, s, OAc). IR: 1740, 1050, 1000. Anal. Calcd for $\mathrm{C}_{9} \mathrm{H}_{12} \mathrm{O}_{6} \mathrm{~S}: \mathrm{C}, 43.55 ; \mathrm{H}, 4.87$. Found: C, 43.62; H, 4.93.

Methyl 2-Deoxy- $\alpha$-D-arabino-hexopyranoside 3,4,6-Triacetate (22b)- - Syrup. ${ }^{1} \mathrm{H}-\mathrm{NMR}\left(\mathrm{CDCl}_{3}\right): 5.26-5.40$ $(1 \mathrm{H}, \mathrm{m}, \mathrm{H}-3), 5.03(1 \mathrm{H}, \mathrm{t}, J=10.0 \mathrm{~Hz}, \mathrm{H}-4), 4.87(1 \mathrm{H}, \mathrm{d}, J=3.5 \mathrm{~Hz}, \mathrm{H}-1), 4.33(1 \mathrm{H}, \mathrm{dd}, J=5.0,12.0 \mathrm{~Hz}, \mathrm{H}-6), 4.08$ $(1 \mathrm{H}, \mathrm{dd}, J=2.5,12.0 \mathrm{~Hz}, \mathrm{H}-6), 3.92-4.01(1 \mathrm{H}, \mathrm{m}, \mathrm{H}-5), 3.37(3 \mathrm{H}, \mathrm{s}, \mathrm{OMe}), 2.28(1 \mathrm{H}, \mathrm{dd}, J=5.5,13.0 \mathrm{~Hz}, \mathrm{H}-2 \mathrm{eq})$, $1.24(1 \mathrm{H}$, ddd, $J=3.5,12.0,13.0 \mathrm{~Hz}, \mathrm{H}-2 \mathrm{ax}), 2.03,2.06$ and $2.12(3 \mathrm{H}$ each, s, OAc).

On deacetylation it gave methyl 2-deoxy- $\alpha$-D-arabino-hexopyranoside (22a) as needles from AcOEt, mp 89$90{ }^{\circ} \mathrm{C} .{ }^{1} \mathrm{H}-\mathrm{NMR}: 4.96(1 \mathrm{H}, \mathrm{d}, J=3.5 \mathrm{~Hz}, \mathrm{H}-1), 4.34(1 \mathrm{H}, \mathrm{dd}, J=5.5,11.5 \mathrm{~Hz}, \mathrm{H}-3), 3.36(3 \mathrm{H}, \mathrm{s}, \mathrm{OMe}), 2.46(1 \mathrm{H}, \mathrm{dd}$, $J=5.5,13.0 \mathrm{~Hz}, \mathrm{H}-2 \mathrm{eq}), 2.02(1 \mathrm{H}$, ddd, $J=3.5,11.5,13.0 \mathrm{~Hz}, \mathrm{H}-2 \mathrm{ax})$. Anal. Calcd for $\mathrm{C}_{7} \mathrm{H}_{14} \mathrm{O}_{5}: \mathrm{C}, 47.18 ; \mathrm{H}, 7.92$. Found: C, 47.04; H, 7.75 .

Methyl 2-Deoxy- $\alpha$-D-threo-pentopyranoside 3,4-Diacetate (23)—Syrup. ${ }^{1} \mathrm{H}-\mathrm{NMR}: 5.57$ (1H, ddd, $J=5.0,9.5$, $10.0 \mathrm{~Hz}, \mathrm{H}-4), 5.17(1 \mathrm{H}, \mathrm{dt}, J=5.0,9.5 \mathrm{~Hz}, \mathrm{H}-3), 4.79(1 \mathrm{H}, \mathrm{dd}, J=2.5,3.5 \mathrm{~Hz}, \mathrm{H}-1), 3.93(1 \mathrm{H}, \mathrm{dd}, J=5.0,11.0 \mathrm{~Hz}, \mathrm{H}-$ 5eq), $3.68(1 \mathrm{H}$, dd, $J=10.0,11.0 \mathrm{~Hz}, \mathrm{H}-5 \mathrm{ax}), 2.29(3 \mathrm{H}, \mathrm{s}, \mathrm{OMe}), 2.33(1 \mathrm{H}, \mathrm{ddd}, J=2.5,5.0,13.0 \mathrm{~Hz}, \mathrm{H}-2 \mathrm{eq}), 1.82(1 \mathrm{H}$, ddd, $J=3.5,9.5,13.0 \mathrm{~Hz}, \mathrm{H}-2 \mathrm{ax}$ ), 2.00 and 2.02 (3H each, s, OAc). HR-MS $m / z$ Calcd for $\mathrm{C}_{10} \mathrm{H}_{16} \mathrm{O}_{6}: 232.0947$. Found: 232.0951

Methyl 4-Deoxy- $\boldsymbol{\beta}$-L-threo-pentopyranoside 2,3-Diacetate (24)-Syrup. ${ }^{1} \mathrm{H}-\mathrm{NMR}$ : $5.60(1 \mathrm{H}$, ddd, $J=5.5,10.0$, $12.0 \mathrm{~Hz}, \mathrm{H}-3), 5.16(1 \mathrm{H}, \mathrm{dd}, J=3.4,10.0 \mathrm{~Hz}, \mathrm{H}-2), 5.12(1 \mathrm{H}, \mathrm{d}, J=3.4 \mathrm{~Hz}, \mathrm{H}-1), 3.70(1 \mathrm{H}, \mathrm{dt}, J=2.5,12.0 \mathrm{~Hz}, \mathrm{H}-5 \mathrm{ax})$, $3.58(1 \mathrm{H}$, ddd, $J=1.8,5.5,12.0 \mathrm{~Hz}, \mathrm{H}-5 \mathrm{eq}), 3.30(3 \mathrm{H}, \mathrm{s}, \mathrm{OMe}), 2.05-2.11(1 \mathrm{H}, \mathrm{m}, \mathrm{H}-4 \mathrm{eq}), 1.78(1 \mathrm{H}, \mathrm{ddd}, J=5.5$, $12.0,12.5 \mathrm{~Hz}, \mathrm{H}-4 \mathrm{ax}$ ), 2.00 and 2.01 ( $3 \mathrm{H}$ each, s, OAc). $\mathrm{HR}-\mathrm{MS} m / z$ Calcd for $\mathrm{C}_{10} \mathrm{H}_{16} \mathrm{O}_{6}: 232.0947$. Found: 232.0950.

Methyl 4-Deoxy- $\alpha$-L-threo-pentopyranoside 2,3-Diacetate (25)—Syrup. ${ }^{1} \mathrm{H}-\mathrm{NMR}: 5.22-5.25(2 \mathrm{H}, \mathrm{m}, \mathrm{H}-2$ and $\mathrm{H}-3), 4.49$ ( $1 \mathrm{H}, \mathrm{d}, J=6.7 \mathrm{~Hz}, \mathrm{H}-1), 3.94(1 \mathrm{H}, \mathrm{dt}, J=3.8,12.0 \mathrm{~Hz}, \mathrm{H}-5 \mathrm{ax}), 3.84$ (1 H, ddd, $J=1.0,2.8,12.0 \mathrm{~Hz}, \mathrm{H}-5 \mathrm{eq})$, $3.43(3 \mathrm{H}, \mathrm{s}, \mathrm{OMe}), 2.05-2.11(1 \mathrm{H}, \mathrm{m}, \mathrm{H}-4), 1.68-1.78(1 \mathrm{H}, \mathrm{m}, \mathrm{H}-4), 1.99$ and 2.01 (3H each, s, OAc). HR-MS $m / z$ Calcd for $\mathrm{C}_{10} \mathrm{H}_{16} \mathrm{O}_{6}: 232.0947$. Found: 232.0954.

Methyl 6-O-Tosyl- $\boldsymbol{\alpha}$-D-glucopyranoside (26)—Needles from AcOEt, mp $118-120$ C. ${ }^{1} \mathrm{H}-\mathrm{NMR}: 8.00(2 \mathrm{H}, \mathrm{d}$, $J=7.6 \mathrm{~Hz}, \mathrm{ArH}), 7.20(2 \mathrm{H}, \mathrm{d}, J=7.6 \mathrm{~Hz}, \mathrm{ArH}), 5.04(1 \mathrm{H}, \mathrm{d}, J=3.7 \mathrm{~Hz}, \mathrm{H}-1), 4.92(1 \mathrm{H}, \mathrm{d}, J=10.5 \mathrm{~Hz}, \mathrm{H}-6), 4.77(1 \mathrm{H}$, dd, $J=5.8,10.5 \mathrm{~Hz}, \mathrm{H}-6), 4.44(1 \mathrm{H}, \mathrm{t}, J=8.9 \mathrm{~Hz}, \mathrm{H}-3), 4.50(1 \mathrm{H}, \mathrm{dd}, J=5.8,8.9 \mathrm{~Hz}, \mathrm{H}-5), 3.97-4.05(2 \mathrm{H}, \mathrm{m}, \mathrm{H}-2 \mathrm{and}$ $\mathrm{H}-4), 3.36(3 \mathrm{H}, \mathrm{s}, \mathrm{OMe}), 2.17$ (3H, s, Me). IR: 3400, 2920, 1351, 1340, 1195, 1160. Anal. Calcd for $\mathrm{C}_{14} \mathrm{H}_{20} \mathrm{O}_{8} \mathrm{~S}: \mathrm{C}_{\text {, }}$ 48.27; H, 5.79. Found: C, 48.23; H, 7.81 .

Methyl 6-Deoxy- $\alpha$-D-glucopyranoside (27) - Methyl $\alpha$-D-glucopyranoside 6-tosylate $(1.4 \mathrm{~g})$ and $\mathrm{LiAlH}_{4}(0.73 \mathrm{~g}$, $4.4 \mathrm{~mol}$ eq) in THF $(100 \mathrm{ml})$ were refluxed for $16 \mathrm{~h}$. After decomposition of the excess reagent by sat. $\mathrm{Na}_{2} \mathrm{SO}_{4}$ aq., the mixture was filtered and the residue was extracted several times with hot AcOEt. The residue was decomposed by adding $1 \mathrm{~N} \mathrm{HCl}$ and neutralized with $\mathrm{NaHCO}_{3}$, then concentrated to dryness, and the residue was extracted 
thoroughly with hot EtOH-AcOEt. All organic extracts were combined and concentrated to dryness and the residue was chromatographed in AcOEt. The AcOEt and AcOEt-EtOH $(99: 1)$ eluates gave 27 in $71 \%$ yield $(550 \mathrm{mg})$ as needles from AcOEt, mp 96-98 C (lit. mp 99 C). ${ }^{11}{ }^{1} \mathrm{H}-\mathrm{NMR}: 5.05(1 \mathrm{H}, \mathrm{d}, J=3.7 \mathrm{~Hz}, \mathrm{H}-1), 4.42(1 \mathrm{H}, \mathrm{t}, J=9.2 \mathrm{~Hz}$, $\mathrm{H}-3), 4.09-4.14(1 \mathrm{H}, \mathrm{m}, \mathrm{H}-5), 4.08(1 \mathrm{H}, \mathrm{dd}, J=3.7,9.2 \mathrm{~Hz}, \mathrm{H}-2), 3.67(1 \mathrm{H}, \mathrm{t}, J=9.2 \mathrm{~Hz}, \mathrm{H}-4), 3.41(3 \mathrm{H}, \mathrm{s}, \mathrm{OMe})$, $1.58(3 \mathrm{H}, \mathrm{d}, J=6.4 \mathrm{~Hz}, 6-\mathrm{Me})$.

Methyl 6-O-Tosyl- $\boldsymbol{\beta}$-D-glucopyranoside (28)-Syrup. ${ }^{1} \mathrm{H}-\mathrm{NMR}: 7.99(2 \mathrm{H}, \mathrm{d}, J=8.0 \mathrm{~Hz}, \mathrm{ArH}), 4.93(1 \mathrm{H}, \mathrm{d}, J=$ $10.0 \mathrm{~Hz}, \mathrm{H}-6), 4.74(1 \mathrm{H}, \mathrm{dd}, J=4.5,10.0 \mathrm{~Hz}, \mathrm{H}-6), 4.61(1 \mathrm{H}, \mathrm{d}, J=8.0 \mathrm{~Hz}, \mathrm{H}-1), 4.11(1 \mathrm{H}, \mathrm{t}, J=8.0 \mathrm{~Hz}, \mathrm{H}-3), 3.94-$ $4.07(2 \mathrm{H}, \mathrm{m}, \mathrm{H}-4$ and $\mathrm{H}-5), 3.89(1 \mathrm{H}, \mathrm{t}, J=8.0 \mathrm{~Hz}, \mathrm{H}-2), 3.52(3 \mathrm{H}, \mathrm{s}, \mathrm{OMe}), 2.18(3 \mathrm{H}, \mathrm{s}, \mathrm{Me})$.

On acetylation it gave a triacetate as colorless needles from hexane- $\mathrm{CH}_{2} \mathrm{Cl}_{2}, \mathrm{mp} 173-175 \mathrm{C}$. ${ }^{1} \mathrm{H}-\mathrm{NMR}$ $\left(\mathrm{CDCl}_{3}\right): 7.78(2 \mathrm{H}, \mathrm{d}, J=8.0 \mathrm{~Hz}, \mathrm{ArH}), 7.35(2 \mathrm{H}, \mathrm{d}, J=8.0 \mathrm{~Hz}, \mathrm{ArH}), 5.17(1 \mathrm{H}, \mathrm{t}, J=9.5 \mathrm{~Hz}, \mathrm{H}-3), 4.91(1 \mathrm{H}, \mathrm{t}, J=$ $9.5 \mathrm{~Hz}, \mathrm{H}-4), 4.89(1 \mathrm{H}, \mathrm{dd}, J=8.0,9.5 \mathrm{~Hz}, \mathrm{H}-2), 4.38(1 \mathrm{H}, \mathrm{d}, J=8.0 \mathrm{~Hz}, \mathrm{H}-1), 4.13(1 \mathrm{H}, \mathrm{dd}, J=3.0,11.0 \mathrm{~Hz}, \mathrm{H}-6)$, $4.08(1 \mathrm{H}, \mathrm{dd}, J=5.5,11.0 \mathrm{~Hz}, \mathrm{H}-6), 3.75(1 \mathrm{H}, \mathrm{ddd}, J=3.0,5.5,9.5 \mathrm{~Hz}, \mathrm{H}-5), 3.44(3 \mathrm{H}, \mathrm{s}, \mathrm{OMe}), 2.46(3 \mathrm{H}, \mathrm{s}, \mathrm{Me}), 1.98$, 2.00, and 2.03 (3H each s, OAc). IR: $2900,1740,1350,1175$. Anal. Calcd for $\mathrm{C}_{20} \mathrm{H}_{26} \mathrm{O}_{11} \mathrm{~S}: \mathrm{C}, 50.63 ; \mathrm{H}, 5.53$. Found: C, $50.35 ; \mathrm{H}, 5.54$

Methyl 6-Deoxy- $\boldsymbol{\beta}$-D-glucopyranoside (29) - Reduction of 28 with LAH was carried out as described for 27, in $68 \%$ yield. After isolation, the product was crystallized from AcOEt as needles, mp 132-133 C (lit. mp 130$131 \mathrm{C}) .{ }^{11)}{ }^{1} \mathrm{H}-\mathrm{NMR}: 4.61(1 \mathrm{H}, \mathrm{d}, J=7.6 \mathrm{~Hz}, \mathrm{H}-1), 4.10(1 \mathrm{H}, \mathrm{t}, J=7.6 \mathrm{~Hz}, \mathrm{H}-3), 3.97(1 \mathrm{H}, \mathrm{t}, J=7.6 \mathrm{~Hz}, \mathrm{H}-2), 3.65-$ $3.80(2 \mathrm{H}, \mathrm{m}, \mathrm{H}-4,5), 3.61(3 \mathrm{H}, \mathrm{s}, \mathrm{OMe}), 1.61(3 \mathrm{H}, \mathrm{d}, J=5.5 \mathrm{~Hz}, 6-\mathrm{Me})$. IR: 3400,2900 . Anal. Calcd for $\mathrm{C}_{7} \mathrm{H}_{14} \mathrm{O}_{5}: \mathrm{C}_{\text {, }}$ 47.18; H, 7.92. Found: C, 46.94; H, 7.92.

Methyl 3-Deoxy- $\boldsymbol{\beta}$-D-xylo-hexopyranoside 2,6-Diacetate (30)-Syrup. ${ }^{1} \mathrm{H}-\mathrm{NMR}$ : $4.93-5.06$ (1H, $\left.\mathrm{m}, \mathrm{H}-2\right)$, $4.38(1 \mathrm{H}, \mathrm{d}, J=6.5 \mathrm{~Hz}, \mathrm{H}-1), 4.34(1 \mathrm{H}, \mathrm{dd}, J=6.5,12.0 \mathrm{~Hz}, \mathrm{H}-6), 4.22(1 \mathrm{H}, \mathrm{dd}, J=6.5,12.0 \mathrm{~Hz}, \mathrm{H}-6), 3.91(1 \mathrm{H}, \mathrm{br}$, $\mathrm{H}-4), 3.76(1 \mathrm{H}, \mathrm{dt}, J=1.0,6.5 \mathrm{~Hz}, \mathrm{H}-5), 3.52(3 \mathrm{H}, \mathrm{s}, \mathrm{OMe}), 2.34-2.45(1 \mathrm{H}, \mathrm{m}, \mathrm{H}-3), 1.58-1.72(1 \mathrm{H}, \mathrm{m}, \mathrm{H}-3), 2.06-$ 2.16 (3H each, $s, \mathrm{OAc}$ ). HR-MS $m / z$ Calcd for $\mathrm{C}_{11} \mathrm{H}_{18} \mathrm{O}_{7}: 262.1052$. Found: 262.1059 .

Methyl 4-Deoxy- $\boldsymbol{\beta}$-D-xylo-hexopyranoside 2,6-Diacetate (31) - Syrup. ${ }^{1} \mathrm{H}-\mathrm{NMR}: 5.27(1 \mathrm{H}, \mathrm{dd}, J=8.0,9.0 \mathrm{~Hz}$, $\mathrm{H}-2), 4.54(1 \mathrm{H}, \mathrm{d}, J=8.0 \mathrm{~Hz}, \mathrm{H}-1), 4.22-4.38\left(2 \mathrm{H}, \mathrm{m}, \mathrm{H}_{2}-6\right), 3.82-3.94(2 \mathrm{H}, \mathrm{m}, \mathrm{H}-3$ and $\mathrm{H}-5), 3.48(3 \mathrm{H}, \mathrm{s}, \mathrm{OMe})$, 2.22 ( $1 \mathrm{H}$, ddd, $J=2.0,5.5,12.5 \mathrm{~Hz}, \mathrm{H}-4 \mathrm{eq}), 1.86(1 \mathrm{H}, \mathrm{t}, J=12.5 \mathrm{~Hz}, \mathrm{H}-4 \mathrm{ax}), 1.98$ and 1.99 (3H each, s, OAc). HR-MS $m / z$ Calcd for $\mathrm{C}_{11} \mathrm{H}_{18} \mathrm{O}_{7}: 262.1052$. Found: 262.1057 .

Methyl 3-Deoxy- $\alpha$-D-xylo-hexopyranoside 2,6-Diacetate (32)-Syrup. ${ }^{1} \mathrm{H}-\mathrm{NMR}$ : $5.75(1 \mathrm{H}$, ddd, $J=3.7,5.2$, $12.0 \mathrm{~Hz}, \mathrm{H}-2), 5.17(1 \mathrm{H}, \mathrm{d}, J=3.7 \mathrm{~Hz}, \mathrm{H}-1), 4.70(1 \mathrm{H}, \mathrm{dd}, J=7.6,11.3 \mathrm{~Hz}, \mathrm{H}-6), 4.60(1 \mathrm{H}, \mathrm{dd}, J=4.6,11.3 \mathrm{~Hz}, \mathrm{H}-6)$, $4.25(1 \mathrm{H}$, br s, H-4), $4.18(1 \mathrm{H}, \mathrm{dd}, J=4.6,7.6 \mathrm{~Hz}, \mathrm{H}-5), 3.44(3 \mathrm{H}, \mathrm{s}, \mathrm{OMe}), 2.37(1 \mathrm{H}, \mathrm{dt}, J=5.2,12.0 \mathrm{~Hz}, \mathrm{H}-3 \mathrm{ax}), 2.13$ ( $1 \mathrm{H}, \mathrm{ddd}, J=3.2,5.2,12.0 \mathrm{~Hz}, \mathrm{H}-3 \mathrm{eq}), 1.99$ and 2.03 (3H each, s, OAc). HR-MS $m /=\mathrm{Calcd}_{\text {for }} \mathrm{C}_{11} \mathrm{H}_{18} \mathrm{O}_{7}: 262.1052$. Found: 262.1047 .

Methyl 4-Deoxy- $\boldsymbol{\alpha}$-D-xylo-hexopyranoside 2,6-Diacetate (33)-Syrup. ${ }^{1} \mathrm{H}-\mathrm{NMR}: 5.21(1 \mathrm{H}, \mathrm{d}, J=3.7 \mathrm{~Hz}, \mathrm{H}-1)$, $5.15(1 \mathrm{H}, \mathrm{dd}, J=3.7,10.0 \mathrm{~Hz}, \mathrm{H}-2), 4.56(1 \mathrm{H}, \mathrm{ddd}, J=2.0,5.0,10.0 \mathrm{~Hz}, \mathrm{H}-3), 4.25-4.33\left(2 \mathrm{H}, \mathrm{m}, \mathrm{H}_{2}-6\right), 4.12-4.18$ $(1 \mathrm{H}, \mathrm{m}, \mathrm{H}-5), 3.36(3 \mathrm{H}, \mathrm{s}, \mathrm{OMe}), 2.27(1 \mathrm{H}, \mathrm{ddd}, J=2.0,5.0,12.5 \mathrm{~Hz}, \mathrm{H}-4 \mathrm{eq}), 1.88(1 \mathrm{H}, \mathrm{ABq}, J=12.5 \mathrm{~Hz}, \mathrm{H}-4 \mathrm{ax}), 1.97$ and 2.03 (3H each, $s$, OAc). HR-MS $m / z$ Calcd for $\mathrm{C}_{11} \mathrm{H}_{18} \mathrm{O}_{7}: 262.1052$. Found: 262.1049 .

Phenyl 3-Deoxy- $\boldsymbol{\beta}$-L-threo-pentopyranoside 2-Acetate (34)-Syrup. ${ }^{1} \mathrm{H}-\mathrm{NMR}$ : $7.04-7.40$ (5H, m, ArH), 5.71 $(1 \mathrm{H}, \mathrm{d}, J=2.5 \mathrm{~Hz}, \mathrm{H}-1), 5.46(1 \mathrm{H}, \mathrm{dt}, J=2.5,3.5 \mathrm{~Hz}, \mathrm{H}-2), 4.39-4.54(1 \mathrm{H}, \mathrm{m}, \mathrm{H}-4), 4.01(1 \mathrm{H}, \mathrm{br} \mathrm{s}, \mathrm{H}-5), 3.98(1 \mathrm{H}, \mathrm{d}$, $J=3.0 \mathrm{~Hz}, \mathrm{H}-5), 2.26\left(2 \mathrm{H}, \mathrm{dd}, J=3.5,7.5 \mathrm{~Hz}, \mathrm{H}_{2}-3\right), 2.08(3 \mathrm{H}, \mathrm{s}, \mathrm{OAc})$. HR-MS $m / z$ Calcd for $\mathrm{C}_{12} \mathrm{H}_{16} \mathrm{O}_{5}: 240.0998$. Found: 240.1001 .

Phenyl 4-Deoxy- $\boldsymbol{\alpha}$-L-threo-pentopyranoside 2-Acetate (35)-Syrup. ${ }^{1} \mathrm{H}-\mathrm{NMR}$ : $7.02-7.37$ (5H, m, ArH), 5.54 $(1 \mathrm{H}, \mathrm{t}, J=8.0 \mathrm{~Hz}, \mathrm{H}-2), 5.30(1 \mathrm{H}, \mathrm{d}, J=8.0 \mathrm{~Hz}, \mathrm{H}-1), 4.16-4.28(1 \mathrm{H}, \mathrm{m}, \mathrm{H}-3), 4.02-4.12(1 \mathrm{H}, \mathrm{m}, \mathrm{H}-5), 3.65(1 \mathrm{H}, \mathrm{dt}$, $J=2.5,11.0 \mathrm{~Hz}, \mathrm{H}-5), 1.88-2.21(2 \mathrm{H}, \mathrm{m}, \mathrm{H}-4), 2.01(3 \mathrm{H}, \mathrm{s}, \mathrm{OAc})$. HR-MS $m / z$ Calcd for $\mathrm{C}_{12} \mathrm{H}_{16} \mathrm{O}_{5}: 240.0998$. Found: 240.1000 .

Treatment of 21 b with Tributyltin Hydride - i) With excess $\mathrm{Bu}_{3} \mathrm{SnH}$ : A toluene solution $(12 \mathrm{ml})$ of $21 \mathbf{b}(80 \mathrm{mg})$, $\mathrm{Bu}_{3} \mathrm{SnH}(470 \mathrm{mg}, 5 \mathrm{~mol} \mathrm{eq})$, and $\mathrm{AIBN}(4 \mathrm{mg})$ was heated at $100^{\circ} \mathrm{C}$ for $1 \mathrm{~h}$ in an argon atmosphere with stirring. Chromatography of the product in benzene-ethyl acetate gave 38 (syrup, $44 \mathrm{mg}$ ), 39 (mp 117-119 C, $20 \mathrm{mg}$ ), and trace amounts of $\mathbf{4 0}$ and $\mathbf{3 6}$.

ii) With $1.5 \mathrm{~mol}$ eq of $\mathrm{Bu}_{3} \mathrm{SnH}$ at $100 \mathrm{C}: 21 \mathbf{b}(100 \mathrm{mg})$ in toluene $(15 \mathrm{ml})$ was deoxygenated with $\mathrm{Bu}_{3} \mathrm{SnH}^{\circ}$ $(175 \mathrm{mg})$ as described above. Four compounds were obtained after chromatography; 38 (30 mg), 39 (25 mg), 40 (syrup, $22 \mathrm{mg}$ ), and $\mathbf{3 6}$ (syrup, $10 \mathrm{mg}$ ) slightly contaminated with $\mathbf{3 7}$.

iii) With $1.5 \mathrm{~mol}$ eq of $\mathrm{Bu}_{3} \mathrm{SnH}$ at $75 \mathrm{C}: \mathbf{2 1 b}(150 \mathrm{mg})$ in toluene $(23 \mathrm{ml})$ was deoxygenated with $\mathrm{Bu}_{3} \mathrm{SnH}(261 \mathrm{mg})$ and AIBN (6 mg) at $75^{\circ} \mathrm{C}$ for $1 \mathrm{~h}$. Chromatography of the product gave $38(35 \mathrm{mg})$ (contaminated with the other compounds), $39(27 \mathrm{mg})$, and an inseparable mixture of 37 and $36(51 \mathrm{mg})$. The ${ }^{1} \mathrm{H}$ - and ${ }^{13} \mathrm{C}-\mathrm{NMR}$ spectra of 37 were obtained by subtraction of the spectra of $\mathbf{3 6}$ from those of the mixture, and confirmed by comparisons of the COSY and $\mathrm{C}-\mathrm{H}$ COSY spectra of the mixture and those of the pure 36. The ratio $(1: 1)$ was determined from the intensity ratio of the OMe peaks.

Methyl 3,4- $\boldsymbol{O}$-Methylidene- $\boldsymbol{\beta}$-L-arabinopyranoside 2-Acetate (38)-Syrup. ${ }^{1} \mathrm{H}-\mathrm{NMR}\left(\mathrm{CDCl}_{3}\right): 5.21$ and 5.00 $\left(1 \mathrm{H}\right.$ each, $\left.\mathrm{s},-\mathrm{OCH}_{2} \mathrm{O}-\right), 4.85(1 \mathrm{H}, \mathrm{d}, J=3.5 \mathrm{~Hz}, \mathrm{H}-1), 4.83(1 \mathrm{H}, \mathrm{dd}, J=3.5,7.5 \mathrm{~Hz}, \mathrm{H}-2), 4.37(1 \mathrm{H}, \mathrm{dd}, J=5.5,7.5 \mathrm{~Hz}$, H-3), 4.07 (1H, d, $J=13.5 \mathrm{~Hz}, \mathrm{H}-5 \mathrm{ax}), 4.04(1 \mathrm{H}, \mathrm{dd}, J=3,5.5 \mathrm{~Hz}, \mathrm{H}-4), 3.92(1 \mathrm{H}, \mathrm{dd}, J=3.0,13.5 \mathrm{~Hz}, \mathrm{H}-5 \mathrm{eq}), 3.40$ 
$(3 \mathrm{H}, \mathrm{s}, \mathrm{OMe}), 2.15(3 \mathrm{H}, \mathrm{s}, \mathrm{OAc}) .{ }^{13} \mathrm{C}-\mathrm{NMR}\left(\mathrm{CDCl}_{3}\right): 170.5(\mathrm{C}=\mathrm{O}), 97.1(\mathrm{C}-1), 94.6\left(-\mathrm{OCH}_{2} \mathrm{O}-\right), 74.5,72.3,70.2(\mathrm{C}-$ 2, 3, 4), 58.2 (C-5), 55.6 (OMe), 21.0 (OAc). HR-MS $m / z$ Calcd for $\mathrm{C}_{9} \mathrm{H}_{14} \mathrm{O}_{6}: 218.0786$. Found: 218.0790.

Methyl $\beta$-L-Arabinopyranoside 3,4-Carbonate 2-Acetate (39)-Colorless needles from hexane- $\mathrm{CH}_{2} \mathrm{Cl}_{2}, \mathrm{mp}$ $117-119^{\circ} \mathrm{C}$. ${ }^{1} \mathrm{H}-\mathrm{NMR}: 5.43(1 \mathrm{H}, \mathrm{dd}, J=3.7,7.3 \mathrm{~Hz}, \mathrm{H}-2), 5.27(1 \mathrm{H}, \mathrm{t}, J=7.3 \mathrm{~Hz}, \mathrm{H}-3), 5.17(1 \mathrm{H}, \mathrm{dd}, J=2.7,7.3 \mathrm{~Hz}$, $\mathrm{H}-4), 5.16(1 \mathrm{H}, \mathrm{d}, J=3.7 \mathrm{~Hz}, \mathrm{H}-1), 4.17$ (1H, d, $J=14.3 \mathrm{~Hz}, \mathrm{H}-5 \mathrm{eq}), 3.98$ (1 H, dd, $J=2.7,14.3 \mathrm{~Hz}, \mathrm{H}-5 \mathrm{ax}), 3.29(3 \mathrm{H}$, s, OMe), $1.99(3 \mathrm{H}, \mathrm{s}, \mathrm{OAc}) .{ }^{13} \mathrm{C}-\mathrm{NMR}: 169.9\left(\mathrm{CH}_{3} \mathrm{C}=\mathrm{O}\right), 154.4\left(\mathrm{O}_{\mathrm{O}}^{\mathrm{O}}=\mathrm{C}=\mathrm{O}\right), 96.6(\mathrm{C}-1), 75.9(\mathrm{C}-4), 74.7(\mathrm{C}-3), 70.8$ (C-2), $57.7(\mathrm{C}-5), 55.8\left(\mathrm{OCH}_{3}\right), 20.5\left(\mathrm{CH}_{3} \mathrm{C}=\mathrm{O}\right)$. IR: 1814, 1724. Anal. Calcd for $\mathrm{C}_{9} \mathrm{H}_{12} \mathrm{O}_{7}: \mathrm{C}, 46.55 ; \mathrm{H}, 5.21$. Found: C, $46.73 ; \mathrm{H}, 5.29$

Methyl 4-Deoxy- $\boldsymbol{\beta}$-L-threo-pentopyranoside 3-Acetate (40)- Syrup. ${ }^{1} \mathrm{H}-\mathrm{NMR}: 5.56(1 \mathrm{H}, \mathrm{dt}, J=5.0,10.5 \mathrm{~Hz}$, $\mathrm{H}-3), 5.06(1 \mathrm{H}, \mathrm{d}, J=4 \mathrm{~Hz}, \mathrm{H}-1), 4.00(1 \mathrm{H}, \mathrm{dd}, J=4.0,10.0 \mathrm{~Hz}, \mathrm{H}-2), 3.74(1 \mathrm{H}, \mathrm{dt}, J=12.0,2.0 \mathrm{~Hz}, \mathrm{H}-5 \mathrm{ax}), 3.60(1 \mathrm{H}$, ddd, $J=2.0,5.0,12.0 \mathrm{~Hz}, \mathrm{H}-5 \mathrm{eq}), 3.37$ (3H, s, OMe), 2.09 ( $1 \mathrm{H}, \mathrm{ddt}, J=12.5,5.0,2.0 \mathrm{~Hz}, \mathrm{H}-4 \mathrm{eq}), 2.01$ (3H, s, OAc), $1.76(1 \mathrm{H}$, ddt, $J=12.5,5.0,10.5 \mathrm{~Hz}, \mathrm{H}-4 \mathrm{ax})$. HR-MS $m / z$ Calcd for $\mathrm{C}_{8} \mathrm{H}_{14} \mathrm{O}_{5}: 190.0841$. Found: 190.0845.

Methyl 4-Deoxy- $\boldsymbol{\beta}$-L-threo-pentopyranoside 2-Acetate (37) ${ }^{1} \mathrm{H}-\mathrm{NMR}: 5.14(1 \mathrm{H}, \mathrm{br} \mathrm{d}, J=3.5 \mathrm{~Hz}, \mathrm{H}-1), 5.12$ $(1 \mathrm{H}, \mathrm{dd}, J=3.5,9 \mathrm{~Hz}, \mathrm{H}-2), 4.46(1 \mathrm{H}, \mathrm{ddd}, J=5,9,11 \mathrm{~Hz}, \mathrm{H}-3), 3.79(1 \mathrm{H}, \mathrm{dt}, J=12.0,2.5 \mathrm{~Hz}, \mathrm{H}-5 \mathrm{ax}), 3.65(1 \mathrm{H}$, ddd, $J=2.0,5.5,12.0 \mathrm{~Hz}, \mathrm{H}-5 \mathrm{eq}), 3.33(3 \mathrm{H}, \mathrm{s}, \mathrm{OMe}), 2.12(1 \mathrm{H}, \mathrm{ddt}, J=12.5,5.0,2.5 \mathrm{~Hz}, \mathrm{H}-4 \mathrm{eq}), 1.97$ (3H, s, OAc), 1.95 ( $1 \mathrm{H}, \mathrm{ddt}, J=5.0,11.0,12.5 \mathrm{~Hz}, \mathrm{H}-4 \mathrm{ax})$.

Methyl 3-Deoxy- $\alpha$-L-threo-pentopyranoside 2-Acetate (36) - Syrup. ${ }^{1} \mathrm{H}-\mathrm{NMR}: 5.74(1 \mathrm{H}, \mathrm{ddd}, J=3,5,11.5 \mathrm{~Hz}$, $\mathrm{H}-2), 5.06(1 \mathrm{H}$, br d, $J=3 \mathrm{~Hz}, \mathrm{H}-1), 4.20-4.24(1 \mathrm{H}, \mathrm{m}, \mathrm{H}-4), 3.92(1 \mathrm{H}, \mathrm{dd}, J=2,12 \mathrm{~Hz}, \mathrm{H}-5 \mathrm{ax}), 3.77(1 \mathrm{H}, \mathrm{dd}, J=2$, $12.0 \mathrm{~Hz}, \mathrm{H}-5 \mathrm{eq}), 3.41$ (3H, s, OMe), 2.33 (1H, ddd, $J=3,11.5,12.5 \mathrm{~Hz}, \mathrm{H}-3 \mathrm{ax}), 2.23$ (1H, ddd, $J=4,5,12.5 \mathrm{~Hz}, \mathrm{H}-$ 3eq), 1.99 (3H, s, OAc). HR-MS $m / z$ Calcd for $\mathrm{C}_{8} \mathrm{H}_{14} \mathrm{O}_{5}: 190.0841$. Found: 190.0848.

Methyl 3,4-Dideoxy- $\boldsymbol{\beta}$-D-erythro-hex-3-enopyranoside 2,6-Diacetate (41b)—Needles from isopropyl ether, $\mathrm{mp}$ $78-80 \mathrm{C}$. ${ }^{1} \mathrm{H}-\mathrm{NMR}\left(\mathrm{CDCl}_{3}\right): 5.91(1 \mathrm{H}, \mathrm{ddd}, J=1.2,1.8,10.4 \mathrm{~Hz}, \mathrm{H}-3), 5.85(1 \mathrm{H}, \mathrm{ddd}, J=2.4,3.0,10.4 \mathrm{~Hz}, \mathrm{H}-4)$, $5.14-5.17(1 \mathrm{H}, \mathrm{m}, \mathrm{H}-2), 4.62(1 \mathrm{H}, \mathrm{d}, J=4.9 \mathrm{~Hz}, \mathrm{H}-1), 4.48-4.54(1 \mathrm{H}, \mathrm{m}, \mathrm{H}-5), 4.19(1 \mathrm{H}, \mathrm{dd}, J=6.4,11.3 \mathrm{~Hz}, \mathrm{H}-6)$, $4.15(1 \mathrm{H}, \mathrm{dd}, J=5.2,11.3 \mathrm{~Hz}, \mathrm{H}-6), 3.50(3 \mathrm{H}, \mathrm{s}, \mathrm{OMe}), 2.09$ and 2.10 (3H each, s, OAc). IR: 1800, 1720. Anal. Calcd for $\mathrm{C}_{11} \mathrm{H}_{16} \mathrm{O}_{6}: \mathrm{C}, 54.09 ; \mathrm{H}, 6.60$. Found: $\mathrm{C}, 54.02 ; \mathrm{H}, 6.63$.

Methyl 3,4-Dideoxy- $\beta$-D-erythro-hex-3-enopyranoside (41a) $\quad$ Syrup. ${ }^{1} \mathrm{H}$-NMR $\left(\mathrm{CDCl}_{3}\right): 5.86(1 \mathrm{H}, \mathrm{dt}, J=10.2$, $2.4 \mathrm{~Hz}, \mathrm{H}-3), 5.74(1 \mathrm{H}, \mathrm{dt}, J=10.2,1.8 \mathrm{~Hz}, \mathrm{H}-4), 4.42(1 \mathrm{H}, \mathrm{d}, J=5.8 \mathrm{~Hz}, \mathrm{H}-1), 4.36-4.41(1 \mathrm{H}, \mathrm{m}, \mathrm{H}-5), 4.08(1 \mathrm{H}, \mathrm{dt}$, $J=5.8,2.4 \mathrm{~Hz}, \mathrm{H}-2), 3.76(1 \mathrm{H}, \mathrm{dd}, J=3.2,12.0 \mathrm{~Hz}, \mathrm{H}-6), 3.62(1 \mathrm{H}, \mathrm{dd}, J=6.0,12.0 \mathrm{~Hz}, \mathrm{H}-6), 3.57$ ( $3 \mathrm{H}, \mathrm{s}, \mathrm{OMe})$.

Methyl 3,4-Dideoxy- $\beta$-D-erythro-hexopyranoside (42)—Volatile liquid. ${ }^{1} \mathrm{H}-\mathrm{NMR}\left(\mathrm{CDCl}_{3}\right): 4.14(1 \mathrm{H}, \mathrm{d}, J=$ $7.6 \mathrm{~Hz}, \mathrm{H}-1), 3.59-3.63\left(3 \mathrm{H}, \mathrm{m}, \mathrm{H}-5\right.$ and $\left.\mathrm{H}_{2}-6\right), 3.56(3 \mathrm{H}, \mathrm{s}, \mathrm{OMe}), 3.39(1 \mathrm{H}$, ddd, $J=5.5,7.6,10.5 \mathrm{~Hz}, \mathrm{H}-2), 2.12$ $(1 \mathrm{H}, \mathrm{ddd}, J=2.5,5.5,10.5 \mathrm{~Hz}, \mathrm{H}-3), 1.59-1.67(1 \mathrm{H}, \mathrm{m}, \mathrm{H}-3), 1.45-1.58\left(2 \mathrm{H}, \mathrm{m}, \mathrm{H}_{2}-4\right)$. HR-MS $m / z$ Calcd for $\mathrm{C}_{7} \mathrm{H}_{14} \mathrm{O}_{4}: 162.0892$. Found: 162.0895 .

Methyl 3,4-Dideoxy- $\alpha$-D-erythro-hex-3-enopyranoside 2,6-Diacetate (43b)—Colorless liquid. ${ }^{1} \mathrm{H}-\mathrm{NMR}$ $\left(\mathrm{CDCl}_{3}\right): 5.84(1 \mathrm{H}, \mathrm{dt}, J=10.7,2.1 \mathrm{~Hz}, \mathrm{H}-3), 5.75(1 \mathrm{H}, \mathrm{dt}, J=10.7,2.1 \mathrm{~Hz}, \mathrm{H}-4), 5.30-5.34(1 \mathrm{H}, \mathrm{m}, \mathrm{H}-2), 5.11(1 \mathrm{H}$, d, $J=4.2 \mathrm{~Hz}, \mathrm{H}-1), 4.36-4.42(1 \mathrm{H}, \mathrm{m}, \mathrm{H}-5), 4.18\left(2 \mathrm{H}, \mathrm{d}, J=4.9 \mathrm{~Hz}, \mathrm{H}_{2}-6\right), 3.50(3 \mathrm{H}, \mathrm{s}, \mathrm{OMe}), 2.10$ and $2.12(3 \mathrm{H}$ each, s, OAc).

Methyl 3,4-Dideoxy- $\boldsymbol{x}$-D-erythro-hex-3-enopyranoside (43a)-Volatile liquid. ${ }^{1} \mathrm{H}-\mathrm{NMR}\left(\mathrm{CDCl}_{3}\right): 5.81(1 \mathrm{H}, \mathrm{dt}$, $J=10.4,2.1 \mathrm{~Hz}, \mathrm{H}-3), 5.69(1 \mathrm{H}, \mathrm{dt}, J=10.4,2.1 \mathrm{~Hz}, \mathrm{H}-4), 4.92(1 \mathrm{H}, \mathrm{d}, J=4.6 \mathrm{~Hz}, \mathrm{H}-1), 4.19-4.26(2 \mathrm{H}, \mathrm{m}, \mathrm{H}-2,5)$, $3.74(1 \mathrm{H}, \mathrm{dd}, J=3.0,11.3 \mathrm{~Hz}, \mathrm{H}-6), 3.60(1 \mathrm{H}, \mathrm{dd}, J=6.1,11.3 \mathrm{~Hz}, \mathrm{H}-6), 3.53(3 \mathrm{H}, \mathrm{s}, \mathrm{OMe})$.

Methyl 3,4-Dideoxy- $\boldsymbol{\alpha}$-D-erythro-hexopyranoside (44)—Volatile liquid. ${ }^{1} \mathrm{H}-\mathrm{NMR}\left(\mathrm{CDCl}_{3}\right): 4.70(1 \mathrm{H}, \mathrm{d}, J=$ $3.7 \mathrm{~Hz}, \mathrm{H}-1), 3.72-3.79(1 \mathrm{H}, \mathrm{m}, \mathrm{H}-5), 3.62(1 \mathrm{H}, \mathrm{dd}, J=3.4,11.6 \mathrm{~Hz}, \mathrm{H}-6), 3.59-3.63(1 \mathrm{H}, \mathrm{m}, \mathrm{H}-2), 3.51(1 \mathrm{H}, \mathrm{dd}, J=$ $6.7,11.6 \mathrm{~Hz}, \mathrm{H}-6), 3.45$ (3H, s, OMe), 1.90 ( $1 \mathrm{H}$, ddd, $J=4.0,5.5,11.5 \mathrm{~Hz}, \mathrm{H}-3 \mathrm{eq}), 1.71$ ( $1 \mathrm{H}$, dddd, $J=4.0,8.0,11.5$, $11.9 \mathrm{~Hz}, \mathrm{H}-3 \mathrm{ax}), 1.61(1 \mathrm{H}$, ddd, $J=3.4,4.0,11.9 \mathrm{~Hz}, \mathrm{H}-4 \mathrm{eq}), 1.48(1 \mathrm{H}$, dddd, $J=4.0,8.0,11.9,11.9 \mathrm{~Hz}, \mathrm{H}-4 \mathrm{ax})$. HRMS $m / z$ Calcd for $\mathrm{C}_{7} \mathrm{H}_{14} \mathrm{O}_{4}: 162.0892$. Found: 162.0898 .

Phenyl 3,4-Dideoxy- $\boldsymbol{\beta}$-D-glycero-pent-3-enopyranoside 2-Acetate (45b)—Syrup. ${ }^{1} \mathrm{H}-\mathrm{NMR}\left(\mathrm{CDCl}_{3}\right): 7.27-7.32$ $(2 \mathrm{H}, \mathrm{m}, \mathrm{ArH}), 7.01-7.09(3 \mathrm{H}, \mathrm{m}, \mathrm{ArH}), 6.17(1 \mathrm{H}, \mathrm{dt}, J=2.5,10.0 \mathrm{~Hz}, \mathrm{H}-4), 4.94-4.98(1 \mathrm{H}, \mathrm{m}, \mathrm{H}-3), 5.56(1 \mathrm{H}$, br s, $\mathrm{H}-1), 5.18(1 \mathrm{H}$, brd, $J=4.0 \mathrm{~Hz}, \mathrm{H}-2), 4.28(1 \mathrm{H}, \mathrm{dd}, J=2.5,17.0 \mathrm{~Hz}, \mathrm{H}-5), 4.02(1 \mathrm{H}, \mathrm{dd}, J=2.5,17.0 \mathrm{~Hz}, \mathrm{H}-5)$.

Phenyl 3,4-Dideoxy- $\beta$-D-glycero-pent-3-enopyranoside (45a) Syrup. ${ }^{1} \mathrm{H}-\mathrm{NMR}\left(\mathrm{CDCl}_{3}\right): 7.00-7.32(5 \mathrm{H}, \mathrm{m}$, ArH), $6.00(2 \mathrm{H}, \mathrm{s}, \mathrm{H}-3$ and H-4), $5.47(1 \mathrm{H}, \mathrm{d}, J=2.1 \mathrm{~Hz}, \mathrm{H}-1), 4.24(1 \mathrm{H}, \mathrm{dd}, J=2.0,17.5 \mathrm{~Hz}, \mathrm{H}-5 \mathrm{ax}), 4.15(1 \mathrm{H}, \mathrm{dd}$, $J=1.2,17.5 \mathrm{~Hz}, \mathrm{H}-5 \mathrm{eq}), 4.08(1 \mathrm{H}$, br s, H-2).

Phenyl 3,4-Dideoxy- $\beta$-D-glycero-pentopyranoside (46) Volatile oil. ${ }^{1} \mathrm{H}-\mathrm{NMR}\left(\mathrm{CDCl}_{3}\right): 7.00-7.31(5 \mathrm{H}, \mathrm{m}$, $\operatorname{ArH}), 5.03(1 \mathrm{H}, \mathrm{d}, J=5.2 \mathrm{~Hz}, \mathrm{H}-1), 3.96(1 \mathrm{H}, \mathrm{ddd}, J=3.5,6.3,11.5 \mathrm{~Hz}, \mathrm{H}-5), 3.76(1 \mathrm{H}, \mathrm{ddd}, J=4.0,5.2,7.8 \mathrm{~Hz}, \mathrm{H}-2)$, $3.58(1 \mathrm{H}, \mathrm{ddd}, J=3.0,7.6,11.5 \mathrm{~Hz}, \mathrm{H}-5), 2.20(1 \mathrm{H}, \mathrm{m}, \mathrm{H}-3), 1.84(1 \mathrm{H}, \mathrm{m}, \mathrm{H}-4), 1.69(1 \mathrm{H}, \mathrm{ddd}, J=4.3,7.8,12.5 \mathrm{~Hz}, \mathrm{H}-$ 3), $1.58-1.66(1 \mathrm{H}, \mathrm{m}, \mathrm{H}-4)$. HR-MS $m / z$ Calcd for $\mathrm{C}_{11} \mathrm{H}_{14} \mathrm{O}_{3}: 194.0943$. Found: 194.0949 .

Methyl 3,4-Dideoxy- $\alpha$-D-glycero-pent-3-enopyranoside 2-Acetate (47b)- Highly volatile liquid. ${ }^{1} \mathrm{H}-\mathrm{NMR}$ $\left(\mathrm{CDCl}_{3}\right): 5.95(1 \mathrm{H}, \mathrm{dt}, J=10.4,2.4 \mathrm{~Hz}, \mathrm{H}-4), 4.66(1 \mathrm{H}, \mathrm{dd}, J=2.4,10.4 \mathrm{~Hz}, \mathrm{H}-3), 5.30(1 \mathrm{H}, \mathrm{m}, \mathrm{H}-2), 4.93(1 \mathrm{H}, \mathrm{d}, J=$ $4.0 \mathrm{~Hz}, \mathrm{H}-1), 4.23(1 \mathrm{H}, \mathrm{dd}, J=2.4,16.8 \mathrm{~Hz}, \mathrm{H}-5), 4.08(1 \mathrm{H}, \mathrm{dd}, J=2.4,16.8 \mathrm{~Hz}, \mathrm{H}-5), 3.50(3 \mathrm{H}, \mathrm{s}, \mathrm{OMe}), 2.12(3 \mathrm{H}, \mathrm{s}$, $\mathrm{OAc})$.

Methyl 3,4-Dideoxy- $\alpha$-D-glycero-pent-3-enopyranoside (47a)—Highly volatile liquid. ${ }^{1} \mathrm{H}-\mathrm{NMR}\left(\mathrm{CDCl}_{3}\right): 5.82$ 
$(1 \mathrm{H}, \mathrm{dt}, J=10.5,2.4 \mathrm{~Hz}, \mathrm{H}-4), 5.73(1 \mathrm{H}, \mathrm{dd}, J=2.1,10.5 \mathrm{~Hz}, \mathrm{H}-3), 4.77(1 \mathrm{H}, \mathrm{d}, J=4.0 \mathrm{~Hz}, \mathrm{H}-1), 4.17-4.21(1 \mathrm{H}, \mathrm{m}$, $\mathrm{H}-2), 4.14(1 \mathrm{H}, \mathrm{dd}, J=2.4,16.8 \mathrm{~Hz}, \mathrm{H}-5), 4.02(1 \mathrm{H}, \mathrm{dd}, J=2.4,16.8 \mathrm{~Hz}, \mathrm{H}-5), 3.53(3 \mathrm{H}, \mathrm{s}, \mathrm{OMe})$.

Methyl 3,4-Dideoxy- $\alpha$-D-glycero-pentopyranoside (48)—Highly volatile liquid. ${ }^{1} \mathrm{H}-\mathrm{NMR}\left(\mathrm{CDCl}_{3}\right): 4.58(1 \mathrm{H}, \mathrm{d}$, $J=3.1 \mathrm{~Hz}, \mathrm{H}-1), 3.61-3.69(1 \mathrm{H}, \mathrm{m}, \mathrm{H}-2), 3.42-3.53\left(2 \mathrm{H}, \mathrm{m}, \mathrm{H}_{2}-5\right), 3.45(3 \mathrm{H}, \mathrm{s}, \mathrm{OMe}), 1.79-1.85(1 \mathrm{H}, \mathrm{m}, \mathrm{H}-3)$, $1.62-1.75\left(3 \mathrm{H}, \mathrm{m}, \mathrm{H}-3\right.$ and $\left.\mathrm{H}_{2}-4\right)$. HR-MS $m / z$ Calcd for $\mathrm{C}_{6} \mathrm{H}_{12} \mathrm{O}_{3}: 132.0787$. Found: 132.0792 .

Acknowledgement One of the author (M. E. H.) is grateful to the Ministry of Education, Science and Culture of Japan for a scholarship. We also thank Miss Y. Ito for technical assistance for some experiments. This work was supported in part by a Grant-in-Aid for Developmental Research (No. 58870102, 1983 and 1984) to Y. T. and K. K. from Ministry of Education, Science and Culture of Japan.

\section{References and Notes}

1) Utilization of Sugars in Organic Syntheses. XVII. Part XVI: M. E. Haque, T. Kikuchi, K. Kanemitsu, and Y. Tsuda, Chem. Pharm. Bull., 34, 430 (1986).

2) a) D. H. R. Barton and S. W. McCombie, J. Chem. Soc., Perkin Trans. 1, 1975, 1574; b) D. H. R. Barton and R. Subramanian, ibid., 1977, 1718; c) T. S. Fuller and R. V. Stick, Aust. J. Chem., 33, 2509 (1980); d) D. H. R. Barton and R. Subramanian, J. Chem. Soc., Chem. Commun., 1977, 867; e) D. H. R. Barton and R. V. Stick, J. Chem. Soc., Perkin Trans. 1, 1975, 1773.

3) Y. Tsuda, M. E. Haque, and K. Yoshimoto, Chem. Pharm. Bull., 31, 1612 (1983).

4) M. E. Haque, T. Kikuchi, K. Yoshimoto, and Y. Tsuda, Chem. Pharm. Bull., 33, 2243 (1985).

5) a) M. Miyazaki and K. Nakahashi, Jpn. Tokkyo Koho, 1322 (1957) [Chem. Abstr., 52, 4684g (1958)]; b) M. J. Robins, J. S. Wilson, and F. Hansske, J. Am. Chem. Soc., 105, 4059 (1983).

6) H. A. Staab and G. Walther, Justus Liebigs Ann. Chem., 657, 98 (1962).

7) B. Classon, P. J. Gregg, and T. Norberg, Acta Chem. Scand., B38, 195 (1984).

8) a) C. Walling, "Free Radicals in Solution," Wiley, New York, 1959; b) Ingold and B. P. Roberts, "Free Radical Substitution Reaction," Wiley-Interscience, New York, 1971.

9) Occurrence of a facile trans-acyl migration between $\mathrm{O}-2$ and O-3 in pyranosides has been proved [K. Yoshimoto and Y. Tsuda, Chem. Pharm. Bull., 31, 4324 (1983)].

10) E. J. Corey and R. A. E. Winter, J. Am. Chem. Soc., 85, 2677 (1963).

11) M. E. Evans, L. Long, Jr., and F. W. Parrish, J. Org. Chem., 33, 1074 (1968). 